University of Tennessee Health Science Center

UTHSC Digital Commons

\title{
Differential Stimulation of Monocytes to Secrete Secretory Leukocyte Protease Inhibitor by Lipopolysaccharide of Periodontal Pathogens
}

Jason Todd Primm

University of Tennessee Health Science Center

Follow this and additional works at: https://dc.uthsc.edu/dissertations

Part of the Periodontics and Periodontology Commons

\section{Recommended Citation}

Primm, Jason Todd, "Differential Stimulation of Monocytes to Secrete Secretory Leukocyte Protease Inhibitor by Lipopolysaccharide of Periodontal Pathogens" (2009). Theses and Dissertations (ETD). Paper 210. http://dx.doi.org/10.21007/etd.cghs.2009.0254.

This Thesis is brought to you for free and open access by the College of Graduate Health Sciences at UTHSC Digital Commons. It has been accepted for inclusion in Theses and Dissertations (ETD) by an authorized administrator of UTHSC Digital Commons. For more information, please contact jwelch30@uthsc.edu. 


\title{
Differential Stimulation of Monocytes to Secrete Secretory Leukocyte Protease Inhibitor by Lipopolysaccharide of Periodontal Pathogens
}

\begin{abstract}
Lipopolysaccharide (LPS), or endotoxin, is the major component of the outer surface of gram-negative bacteria. LPS is a potent activator of cells of the immune and inflammatory systems, including macrophages, monocytes, and endothelial cells, and contributes to systemic changes known as septic shock. Each LPS molecule has three regions: oligosaccharide, core, and lipid A. Oligosaccharide is exposed on the cell surface, and lipid A anchors LPS in the outer membrane. Recent studies from our lab demonstrated that LPS of periodontal pathogens suppresses neutrophil's ability to secrete super oxide ions and also shown it to interfere with neutrophil chemotaxis. These factors are believed to aid the pathogens to remain "stealthy" and avoid killing by the mononuclear phagocyte cells. Secretory Leukocyte Protease Inhibitor (SLPI) is a single-chain serine protease inhibitor secreted from secretary and inflammatory cells that protects tissue from damage caused by the inflammatory response. The present study examined the interaction of LPS prepared from periodontal pathogens with monocytes to stimulate them to secrete SLPI. The hypothesis of this study is that (1) LPS molecules of more pathogenic periodontal pathogens are better inducer of monocots to secrete SLPI, and (2) Secreted SLPI in turn inhibits the production of inflammatory cytokines produced by monocytes in response to LPS. The limited stimulation of monotypic cells to secrete super oxide ions as shown previously along with the proposed hypothesis that pathogenic organisms produces more SLPI to suppress the inflammatory cytokines may aid the pathogens to remain undetected by mononuclear phagocytes. The LPS from three different periodontal pathogens, Porphyromonas gingivalis, Prevotella denticola, and Fusobacterium nucleatum were isolated for this study under identical conditions. Cultured human monocytic cells were incubated with LPS and the amounts of SLPI secreted were measured. Monocytic cells were also incubated with endogenous SLPI along with LPS of the selected periodontal pathogens and the secretion of the cytokines IL-1 $\beta$ and TNF- $\alpha$ was measured by ELISA. The results demonstrated that LPS of periodontal pathogens differ in their ability to stimulate inflammatory cytokines. Pathogenic strains appear to induce secretion of greater amounts of cytokines than the less pathogenic organisms. Pathogenic organisms tested also showed to induce the cultured THP-1 cells to secrete SLPI. In the presence of exogenous SLPI, the amounts of inflammatory cytokines secreted by THP cells when stimulated with LPS appeared to be diminished. The long-term objective is to understand the mechanisms, by which the periodontal pathogens escape detection by human defensive cells, colonize the gingival tissue and cause severe periodontitis. Understanding the evasive mechanisms by which pathogenic microorganisms escape detection or stimulate the host cells to secrete proteins, such as SLPI, which suppresses production of inflammatory cytokines, may aid the pathogenic organisms to survive in the oral cavity and continue their pathogenic effects.
\end{abstract}

\section{Document Type}

Thesis

\section{Degree Name}

Master of Dental Science (MDS)

\section{Program}

Periodontology

Research Advisor

Jegdish Babu Ph.D. 


\section{Keywords}

LPS, Periodontitis, SLPI

\section{Subject Categories}

Dentistry | Medicine and Health Sciences | Periodontics and Periodontology 
Differential Stimulation of Monocytes to Secrete Secretory Leukocyte Protease Inhibitor by Lipopolysaccharide of Periodontal Pathogens

\author{
A Thesis \\ Presented for \\ The Graduate Studies Council \\ The University of Tennessee \\ Health Science Center
}

\author{
In Partial Fulfillment \\ Of the Requirements for the Degree \\ Master of Dental Science \\ From The University of Tennessee
}

By

Jason Todd Primm D.D.S.

May 2009 
Copyright $\odot 2009$ Jason T. Primm All rights reserved 


\section{DEDICATION}

I dedicate this thesis to my fiancée and love of my life, Kelli Illyes, and my family for their everlasting love and support. 


\section{ACKNOWLEDGEMENTS}

I would like to express my sincere appreciation and thanks to Dr. Jegdish Babu for being a fantastic mentor throughout this master's thesis project and for allowing me to be part of his ongoing studies. I can't thank him enough for his time and effort spent with me in order to make this project possible.

I would like to thank my Committee members Drs. Predeep C. Adatrow, Sidney Stein, Edwin L. Thomas, and David A. Tipton for their valuable support and suggestions.

I am also grateful to The University of Tennessee Health Science Center, College of Dentistry Alumni Endowment Fund for its financial support of this project. 


\begin{abstract}
Lipopolysaccharide (LPS), or endotoxin, is the major component of the outer surface of gram-negative bacteria. LPS is a potent activator of cells of the immune and inflammatory systems, including macrophages, monocytes, and endothelial cells, and contributes to systemic changes known as septic shock. Each LPS molecule has three regions: oligosaccharide, core, and lipid A. Oligosaccharide is exposed on the cell surface, and lipid A anchors LPS in the outer membrane. Recent studies from our lab demonstrated that LPS of periodontal pathogens suppresses neutrophil's ability to secrete super oxide ions and also shown it to interfere with neutrophil chemotaxis. These factors are believed to aid the pathogens to remain "stealthy" and avoid killing by the mononuclear phagocyte cells. Secretory Leukocyte Protease Inhibitor (SLPI) is a singlechain serine protease inhibitor secreted from secretary and inflammatory cells that protects tissue from damage caused by the inflammatory response. The present study examined the interaction of LPS prepared from periodontal pathogens with monocytes to stimulate them to secrete SLPI. The hypothesis of this study is that (1) LPS molecules of more pathogenic periodontal pathogens are better inducer of monocots to secrete SLPI, and (2) Secreted SLPI in turn inhibits the production of inflammatory cytokines produced by monocytes in response to LPS. The limited stimulation of monotypic cells to secrete super oxide ions as shown previously along with the proposed hypothesis that pathogenic organisms produces more SLPI to suppress the inflammatory cytokines may aid the pathogens to remain undetected by mononuclear phagocytes.
\end{abstract}

The LPS from three different periodontal pathogens, Porphyromonas gingivalis, Prevotella denticola, and Fusobacterium nucleatum were isolated for this study under identical conditions. Cultured human monocytic cells were incubated with LPS and the amounts of SLPI secreted were measured. Monocytic cells were also incubated with endogenous SLPI along with LPS of the selected periodontal pathogens and the secretion of the cytokines IL-1 $\beta$ and TNF- $\alpha$ was measured by ELISA.

The results demonstrated that LPS of periodontal pathogens differ in their ability to stimulate inflammatory cytokines. Pathogenic strains appear to induce secretion of greater amounts of cytokines than the less pathogenic organisms. Pathogenic organisms tested also showed to induce the cultured THP-1 cells to secrete SLPI. In the presence of exogenous SLPI, the amounts of inflammatory cytokines secreted by THP cells when stimulated with LPS appeared to be diminished.

The long-term objective is to understand the mechanisms, by which the periodontal pathogens escape detection by human defensive cells, colonize the gingival tissue and cause severe periodontitis. Understanding the evasive mechanisms by which pathogenic microorganisms escape detection or stimulate the host cells to secrete proteins, such as SLPI, which suppresses production of inflammatory cytokines, may aid the pathogenic organisms to survive in the oral cavity and continue their pathogenic effects. 


\section{TABLE OF CONTENTS}

CHAPTER 1. INTRODUCTION AND LITERATURE REVIEW ...................1

Periodontal Pathogens and Periodontal Disease .......................................................... 1

Lipopolysaccharide and Gram-Negative Bacteria ....................................................2

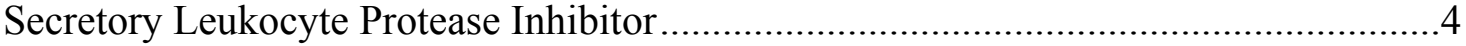

CHAPTER 2. SPECIFIC OBJECTIVES ........................................6

Specific Aim 1: Influence of Periodontal Pathogens on Monocytes to Secrete SLPI ....6

Specific Aim 2: Cytokine Expression by SLPI-Influenced Monocytes ........................6

CHAPTER 3. MATERIALS AND METHODS.........................................7

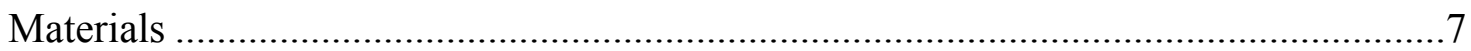

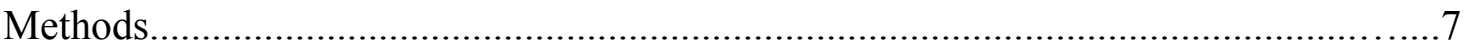

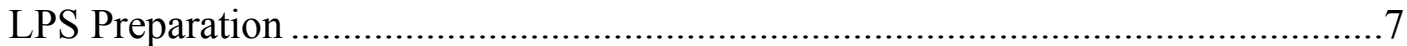

Limulus Amoebocyte Lysate (LAL) Assays.........................................................

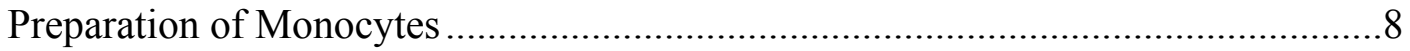

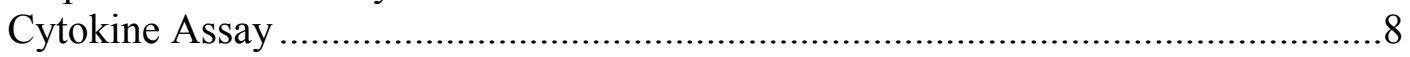

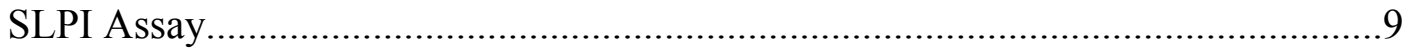

Cytokine Assay Combined with Exogenous SLPI ….......................................10

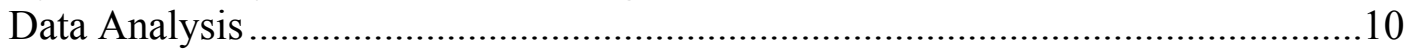

CHAPTER 4. RESULTS.......................................................................................11

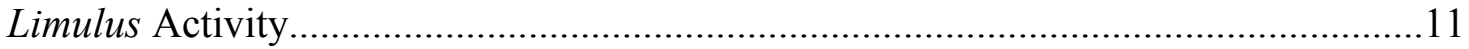

Influence of Periodontal Pathogens on Monocytes to Secrete SLPI and Cytokines .....11

TNF- $\alpha$ Secretion by THP-1 Cells in Response to LPS of Periodontal Pathogens.........11

IL-1 $\beta$ Secretion by THP-1 Cells in Response to LPS of Periodontal Pathogens ..........13

SLPI Secretion by THP-1 Cells in Response to LPS of Periodontal Pathogens ...........16

Effect of Exogenous SLPI on THP-1 Cells Stimulated with LPS of $P g$ on the

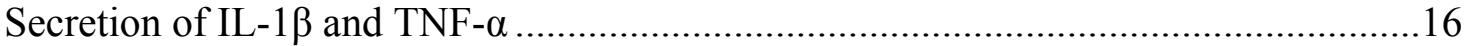

Effect of Exogenous SLPI on THP-1 Cells Stimulated with LPS of $P d$ on the

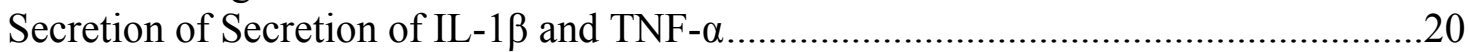

Effect of Exogenous SLPI on THP-1 Cells Stimulated with LPS of Fn on the

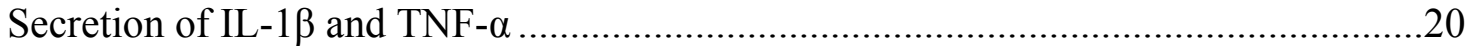

Effect of Exogenous SLPI on THP-1 Cells Stimulated with LPS of $E c$ on the

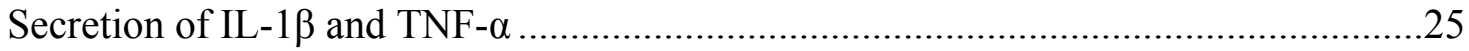

CHAPTER 5. DISCUSSION ...........................................................................................28

TNF- $\alpha$ Secretion by THP-1 Cells in Response to LPS of Periodontal Pathogens.........28

IL-1 $\beta$ Secretion by THP-1 Cells in Response to LPS of Periodontal Pathogens ..........29

SLPI Secretion by THP-1 Cells in Response to LPS of Periodontal Pathogens ...........29

Effect of Exogenous SLPI on Cultured THP-1 Cells Stimulated with LPS of $P g, P d$, and $F n$ on the Secretion of IL- $1 \beta$ and TNF- $\alpha$ 


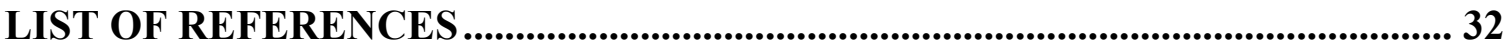

VITA 


\section{LIST OF FIGURES}

Figure 1.1 Diagram Representing the Structure of LPS...............................................

Figure 4.1 Endotoxin Activity of LPS Preparations from E. coli and Oral

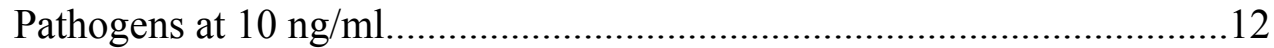

Figure 4.2 Demonstration of TNF- $\alpha$ Secretion by Cultured THP Cells in Response

to LPS of Periodontal Pathogens...................................................................14

Figure 4.3 Demonstration of IL-1 $\beta$ Secretion by Cultured THP Cells in Response to LPS of Periodontal Pathogens..............................................................15

Figure 4.4 Demonstration of SLPI Secretion by Cultured THP Cells in Response to LPS of Periodontal Pathogens..............................................................17

Figure 4.5 Effect of Exogenous SLPI on Cultured THP Cells Stimulated with LPS

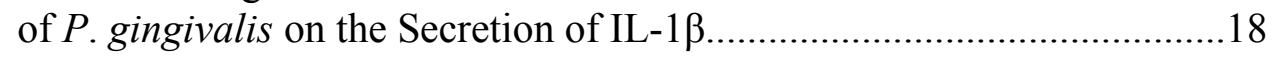

Figure 4.6 Effect of Exogenous SLPI on Cultured THP Cells Stimulated with LPS of $P$. gingivalis on the Secretion of TNF- $\alpha$...............................................19

Figure 4.7 Effect of Exogenous SLPI on Cultured THP Cells Stimulated with LPS

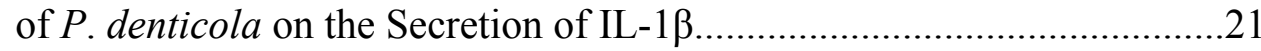

Figure 4.8 Effect of Exogenous SLPI on Cultured THP Cells Stimulated with LPS of $P$. denticola on the Secretion of TNF- $\alpha$.................................................22

Figure 4.9 Effect of Exogenous SLPI on Cultured THP Cells Stimulated with LPS

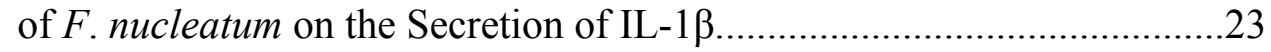

Figure 4.10 Effect of Exogenous SLPI on Cultured THP Cells Stimulated with LPS of $F$. nucleatum on the Secretion of TNF- $\alpha$..............................................24

Figure 4.11 Effect of Exogenous SLPI on Cultured THP Cells Stimulated with LPS

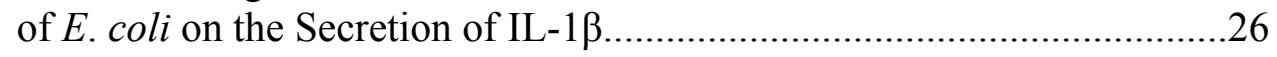

Figure 4.12 Effect of Exogenous SLPI on Cultured THP Cells Stimulated with LPS of $E$. coli on the Secretion of TNF- $\alpha$ 


\section{LIST OF ABBREVATIONS}

\begin{tabular}{|c|c|}
\hline$\mu \mathrm{g} / \mathrm{ml}$ & Microgram Per Milliliter \\
\hline$\mu 1$ & Microliter \\
\hline$\mu \mathrm{M}$ & Micromolar \\
\hline$A a$ & Aggregatibacter actinomycetemcomitans \\
\hline ATCC & American Type Culture Collection \\
\hline BSA & Bovine Serum Albumin \\
\hline $\mathrm{CO}_{2}$ & Carbon Dioxide \\
\hline DNA & Deoxyribose Nucleic Acid \\
\hline E. coli & Escherichia coli \\
\hline ELISA & Enzyme-Linked Immunosorbent Assay \\
\hline fMLP & Formylmethionyl-Leucyl-Phenylalanine \\
\hline Fn & Fusobacterium nucleatum \\
\hline $\mathrm{HCl}$ & Hydrochloric Acid \\
\hline HIV-1 & Human Immunodeficiency Virus-1 \\
\hline IFN- $\gamma$ & Interferon Gamma \\
\hline $\operatorname{IgG}$ & Immunoglobulin $\mathrm{G}$ \\
\hline IL- $1 \alpha$ & Interleukin-1-Alpha \\
\hline IL-1 $\beta$ & Interleukin-1-Beta \\
\hline IL-6 & Interleukin-6 \\
\hline IL-8 & Interleukin-8 \\
\hline IL-12 & Interleukin-12 \\
\hline $\mathrm{kD}$ & Kilodalton \\
\hline
\end{tabular}




\begin{tabular}{|c|c|}
\hline $\mathrm{KDO}$ & 3-Deoxy-D-Manno-Octulosonic Acid \\
\hline LAL & Limulus Amebocyte Lysate \\
\hline LPS & Lipopolysaccharide \\
\hline LTA & Lipoteichoic Acid \\
\hline M & Molar \\
\hline MMP & Matrix Metalloproteinases \\
\hline $\mathrm{N}$ & Normal \\
\hline NADPH & Nicotinamide-Adenine Dinucleotide Phosphate \\
\hline $\mathrm{ng} / \mathrm{ml}$ & Nanogram Per Milliliter \\
\hline $\mathrm{nm}$ & Nanometer \\
\hline PAF & Platelet-Activating Factor \\
\hline PAI-1 & Plasminogen Activator Inhibitor-1 \\
\hline PBS & Phosphate Buffered Saline \\
\hline$P d$ & Prevotella denticola \\
\hline$P g$ & Porphyromonas gingivalis \\
\hline $\mathrm{pg} / \mathrm{ml}$ & Picograms Per Milliliter \\
\hline $\mathrm{PGE}_{2}$ & Prostaglandin $E_{2}$ \\
\hline$P i$ & Prevotella intermedia \\
\hline PMN & Polymorphonuclear Leukocyte \\
\hline SLPI & Secretory Leukocyte Protease Inhibitor \\
\hline$T f$ & Tannerella forsythensis \\
\hline THP-1 & Human Acute Monocytic Leukemia Cell Line \\
\hline TNF- $\alpha$ & Tumor Necrosis Factor-Alpha \\
\hline
\end{tabular}




\section{CHAPTER 1. INTRODUCTION AND LITERATURE REVIEW}

\section{Periodontal Pathogens and Periodontal Disease}

Periodontal disease is a chronic polymicrobial infection caused mainly by gramnegative, motile, strictly anaerobic microorganisms that leads to the destruction of tooth supporting tissue using a variety of immunopathogenic mechanisms. The gingival sulcus hosts a complex microbial ecosystem. At this time over 500 different species of bacteria in the oral cavity have been identified although only few are known to be associated with periodontal disease, among these are Porphyromonas gingivalis, Tannerella forsythia, and Fusobacterium nucleatum $(1,2)$. Tissue damage in the oral cavity was associated with the presence of these organisms through the production of various virulence factors including: fimbriae, capsule and endotoxin, and through deregulation of the host's innate and acquired immunity systems (3). It has been shown that different combinations of indigenous bacteria have the potential to cause progression from gingivitis to periodontitis. Slots (4) studied adults with advanced periodontitis and reported Aggregatibacter actinomycetemcomitans $(\mathrm{Aa})$ in $50 \%$ of progressing lesions but in only $6 \%$ of non-progressing lesions. $P$. gingivalis was seen in $42 \%$ to $52 \%$ of progressing lesions and from $14 \%$ of non-progressing sites. P. intermedia was found in 59\% to $89 \%$ of progressing lesions and from $36 \%$ to $53 \%$ of non-progressing sites (4).

Periodontitis progresses due to the interaction between the pathogenetic bacteria's production of endotoxin and the host immune cells. These interactions will lead to an immune response, which will result in the production of various cytokines, such as Interleukin-1-alpha (IL-1 $\alpha$ ), Interleukin-1-Beta (IL-1 $\beta$ ), Interleukin-6 (IL-6), and Tumor Necrosis Factor-alpha (TNF- $\alpha$ ), which dictate the rate and progression of periodontal tissue destruction by activating an inflammatory reaction (5-7). Endotoxin allows the bacteria to colonize subgingivally, resist the immune system, and cause tissue destruction (8). The LPS from gram-negative organisms such as $A a$ and $P$. gingivalis were shown to stimulate inflammatory cells like polymorphonuclear leukocytes (PMNs) to release several cytokines including IL- $1 \alpha$, IL-1 $\beta$ and TNF- $\alpha$. It has been shown that IL- $1 \alpha$ and TNF- $\alpha$ can activate osteoclastic bone resorption indirectly by stimulating stromal cells $(9,10)$. IL-1 $\beta$ was originally named osteoclast-activating factor because of its resorptive properties in bone cell cultures (11). In addition, the LPS of different gram-negative bacteria have been shown to stimulate bone resorption in an organ culture system (10). For example, $P$. intermedia LPS plays a major role in the peripheral bone resorption process mediated by prostaglandin $\mathrm{E}_{2}\left(\mathrm{PGE}_{2}\right)(12)$. Increased permeability and neutrophil infiltration has resulted from the LPS induced $\mathrm{PGE}_{2}$ production (13). It has been advocated that PMNs actions result in local tissue injury by becoming hyperactive in response to bacterial infection and are primed for actions that result in tissue breakdown (14).

TNF- $\alpha$ is a cytokine originally thought to play a role in host surveillance against neoplasms. Endotoxin-stimulated macrophages are the most important source of TNF- $\alpha$. TNF- $\alpha$ was initially identified as a factor produced by leukocytes and was thought to be 
responsible for infection-induced cachexia. It has been recognized subsequently that TNF has a broader range of effects on host immune responsiveness, such as enhancing polymorphonuclear neutrophil-endothelial interactions and facilitating phagocytosis and bacterial killing. Recently, a role for TNF in the generation of free radicals and the pathophysiological changes during sepsis and septic shock has been proposed (5). Monocytes are thought to play an important role in the immunopathogenesis of periodontal diseases. They are attracted to an area of infection and differentiate into macrophages. Some appear to be primarily phagocytic whereas some function as antigen-processing cells (14). Monocytes also produce substances that are involved in perpetuation of inflammation and result in tissue destruction called cytokines. Cytokines are intercellular signals that function to regulate cellular activity. Monocytes produce IL-1 $\beta$ and TNF- $\alpha$ cytokines that exert inflammatory effects on the injured target cells in the host (15).

\section{Lipopolysaccharide and Gram-Negative Bacteria}

Lipopolysaccharides (LPS) is a major constituent of the outer membrane of gram-negative bacteria and are found in all gram-negative bacteria. A typical bacterium has approximately three-and-one-half million LPS molecules (16). The LPS molecule (Figure 1.1) consists of a covalently attached hydrophobic domain known as lipid A or endotoxin, a non-repeating core oligosaccharide, and a distal polysaccharide or $\mathrm{O}$-antigenic side chain. The most essential part is lipid A, a covalently linked component of LPS that anchors the LPS molecule in the bacterial outer membrane. Lipid A is hydrophobic, glucosamine-based phospholipid that comprises the outer monolayer of the outer membranes of most Gram-negative bacteria (17). The lipid A component generally consists of six or more fatty acid residues linked to two phosphorylated glucosamine sugars. Four of these fatty acids carry a hydroxyl group on the third carbon, while the other two are not hydroxylated (18). Lipid A is bound to the core through an 8-carbon sugar, 2-keto-3-deoxyoctonate (KDO) lipid A linkage. The core can be divided into an inner core and an outer core. The inner core, which consists of two or more 2-keto-3-deoxyoctonic acid (KDO) sugars linked to the lipid A glucosamine and two or three heptose (L-glycero-D-manno-heptose) sugars linked to the KDO. The outer core consists of common sugars and is more variable than the inner core. It normally consists of L-glycero-D-manno-heptose or D-glycero-L-mannoheptose and a variety of hexoses $(19,20)$. The core is attached to the $\mathrm{O}$-antigen via glycoside linkage. The $\mathrm{O}$-antigen is highly immunogenic and is composed of units of common sugars, but there is a huge interspecies and interstrain variation in the composition and length. In a single LPS preparation, the length of the O-antigen may vary from zero to as many as forty repeating units, but it generally consists of 20 to 40 repeating units. Serotype specificity is determined by this variability of repeating saccharide units (21). Each unit is composed of three sugars with a single sugar connected to the first and third sugar of the unit. LPS molecules with O-antigen are denoted S-LPS. Colonies from bacteria with O-antigen-containing LPS have a smooth (S) appearance on the plate, while bacteria that express an O-antigen-lacking LPS have a rough (R) appearance (22). The LPS from several oral anaerobic species also exhibited various chemical compositions (23). The 


\section{Lipopolysaccharide}

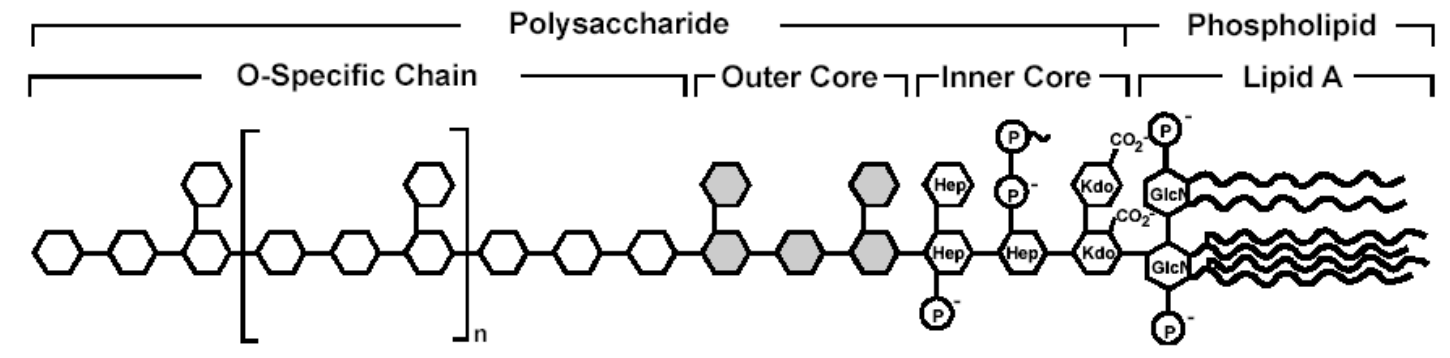

Figure 1.1 Diagram Representing the Structure of LPS.

The diagram represents sugars as hexagons. 
composition of the O-side chain varies between different Gram-negative bacterial strains. $\mathrm{O}$-side chains are easily recognized by the antibodies of the host; however, the nature of the chain can easily be modified by Gram-negative bacteria to avoid detection (24). In addition, the optimal immune activating lipid A structure was shown to contain 6 acyl chains. The length of the carbon chains usually varies between $\mathrm{C} 10$ and $\mathrm{C} 16$, with some exceptions. The lipid A of E.coli typically has five C14 and one C12 (25). Variations in structure result from the type of hexosamine and phosphate substituents present, the degree of phosphorylation, and most importantly the nature, chain length, number, and location of acyl groups (16). Therefore, the chemical composition of LPS can be modified in order to present a specific sugar structure.

Lynn et al. (26) reported that most of the biological activities of LPS were linked to their lipid A portion, which has a structure that is constant among different species, compared with the polysaccharide side chains. LPS and other bacterial (surface) components are recognized by complement and antibodies, leading to opsonisation and lysis of the bacterium. Phagocytes (monocytes, macrophages, and polymorphonuclear leukocytes) are able to recognize opsonized bacterial components by complement receptors and Fc receptors that bind immunoglobulin $\mathrm{G}[\mathrm{IgG}]$ antibodies. Recognition of LPS or other bacterial components by these cells initiates a cascade of release of inflammatory mediators, vascular and physiological changes, and recruitment of immune cells. An LPS-activated macrophage becomes metabolically active and produces intracellular stores of oxygen free radicals and other microbiocidal agents (lysozyme, cationic proteins, acid hydrolases, and lactoferrin) and secretes inflammatory mediators. After exposure to LPS, TNF- $\alpha$ is one of the first cytokines released by macrophages. The release of TNF- $\alpha$, IL-1, IL-6, IL-8, IL-12, platelet-activating factor (PAF), chemokines, and eicosanoids has profound effects on the surrounding tissue. The actions of the activated immune cells combined with the effects of the inflammatory mediators cause symptoms such as fever, endothelial damage, capillary leakage, peripheral vascular dilatation, coagulation disorders, microthrombi, and myocardial depression. These phenomena may finally result in multiple organ dysfunction, shock, and death $(27,28)$.

\section{Secretory Leukocyte Protease Inhibitor}

Secretory leukocyte protease inhibitor (SLPI) is produced by secretory cells in respiratory, genital and lacrimal glands, and by inflammatory cells that include macrophages, neutrophils, and B cells (29). SLPI is an $11.7 \mathrm{kD}$ (107 amino acid), nonglycosylated, single-chain serine protease inhibitor (30). Specifically, SLPI is comprised of two homologous cysteine-rich domains of 53 and 54 amino acids. SLPI inhibits several serine proteases. Examples are elastase and cathepsin $\mathrm{G}$ secreted from neutrophils, trypsin and chymotyrpsin from pancreatic acinar cells, and chymase and tryptase from mast cells (31). Therefore, a major physiological role of SLPI is considered to be the protection of tissue from these proteases at sites of inflammation. However, recent studies have demonstrated that SLPI functions as more than just a protease inhibitor. SLPI suppresses bacterial growth, inhibits infection of lymphocytes by human immunodeficiency virus-1 (HIV-1), ameliorates bacterial arthritis, and 
decreases production of $\mathrm{PGE}_{2}$ and matrix metalloproteinases (MMP)-1 and $9(32,33)$. SLPI is involved in normal cutaneous wound healing, a result previously shown in a study on SLPI deficient mice (34). Moreover, SLPI modifies macrophage function in mice, as shown by the fact that ectopic expression of SLPI cDNA in macrophages increases their resistance to LPS, and that SLPI suppresses macrophages response to LPS (35). Consistently, serum SLPI levels are elevated in endotoxin shock in humans (36). These observations strongly suggest that SLPI is an important participant in innate immunity where it acts as an anti-inflammatory molecule. LPS is among the most potent molecular stimuli of the immune system. SLPI in gingival crevicular fluids has been shown to promote the healing of periodontal tissue after clinical treatment for chronic periodontitis (37). P. gingivalis releases cysteine proteinases that digest SLPI, leading to inactivation of its functions and may attenuate the host protective response including loss of neutralization of neutrophil-derived proteases and susceptible responses to bacterial toxins (38). 


\section{CHAPTER 2. SPECIFIC OBJECTIVES}

The objective of this investigation was to study the interaction of LPS isolated from three periodontal pathogens, $P$. gingivalis, $P$. denticola, and $F$. nucleatum with cultured human monocytes. Monocyte ability to secrete SLPI when induced with LPS was determined. SLPI has been shown to be secreted by human monocytic cells. In the second part of this study, we tested the effect of SLPI on LPS-stimulated secretion of inflammatory cytokines by the monocytes, since the SLPI has been shown to suppress the production of these cytokines.

This study tested the hypothesis that virulent periodontal pathogens suppress the production of inflammatory cytokines initially, by stimulating the monocytes to secrete SLPI. Once the SLPI is secreted which in turn suppresses the production of cytokines by the monocytes, which will help the pathogens to prevail in the oral cavity and colonize successfully, leading to severe periodontitis. Preliminary data from studies demonstrated that LPS of periodontal pathogens induced the monocytes to secrete significant amount of SLPI. Addition of exogenous SLPI along with LPS, suppressed the levels of secretion of inflammatory cytokines. Suppressing the inflammatory cytokines at an initial stage of infection by the periodontal pathogens may allow the pathogens to proliferate and survive in the host and cause severe periodontal disease.

\section{Specific Aim 1: Influence of Periodontal Pathogens on Monocytes to Secrete SLPI}

Determine the influence of LPS isolated from periodontal pathogens, $P$. gingivalis, $P$. denticola, and $F$. nucleatum on the cultured human monocytic cells to secrete SLPI. The amount of SLPI secreted will be measured by ELISA.

\section{Specific Aim 2: Cytokine Expression by SLPI-Influenced Monocytes}

Evaluate the influence of exogenous SLPI on LPS-induced secretion of inflammatory cytokines, IL-1 $\beta$ and TNF- $\alpha$ by the monocytic cells. The amounts of TNF- $\alpha$ and IL-1 $\beta$ produced by the human monocytic cells exposed to LPS + SLPI will be measured by ELISA. 


\section{CHAPTER 3. MATERIALS AND METHODS}

\section{Materials}

The bacteria, $P$. gingivalis (25260), $P$. denticola (33185), and $F$. nucleatum (10953), were obtained from ATCC, Rockville, MD. The bacteria were grown in the laboratory under anaerobic conditions in thioglycollate broth at $37^{\circ} \mathrm{C}$ in an anaerobic jar for 72 hours. SLPI was purchased commercially from R\&D Systems. THP-1 cells (ATCC TIB202) were obtained from ATCC, Rockville, MD. Commercial enzymelinked immunosorbent assay (ELISA) kits from R\&D Systems were employed to measure the cytokines TNF- $\alpha$ and IL-1 $\beta$ released by the monocytes. ELISA kit from R\&D Systems was also used to measure the SLPI secreted by monocytes. LPS from E. coli was purchased from Sigma.

\section{Methods}

\section{LPS Preparation}

Bacteria were grown in one-liter quantities in thioglycollate broth (Difco) for 72 hours in an anaerobic jar. The bacteria were harvested by centrifugation and the cell pellets were washed with physiological saline, then with de-ionized water and centrifuged. The bacterial cell pellets were lyophilized and the LPS was prepared by the hot phenol-water extraction method as described by Westphal and Jann (39). Batches of $0.25 \mathrm{~g}$ of the lyophilized bacteria were suspended in $200 \mathrm{ml}$ of $90 \%$ phenol and water and incubated at $67^{\circ} \mathrm{C}$ for 15 minutes and then stirred for another 15 minutes on a stirrer at room temperature. The mixture was chilled on ice to $10^{\circ} \mathrm{C}$ to separate the phases. The resultant LPS-containing aqueous phase was then collected from the lower phenol phase. The non-aqueous phenol phase was subjected to a second extraction by adding an additional $200 \mathrm{ml}$ of water. The pooled aqueous phase was dialyzed against distilled water at $4^{\circ} \mathrm{C}$ for 48 hours. The aqueous phase was collected and frozen using liquid nitrogen and then lyophilized. The purity and protein contamination of the isolated LPS was confirmed by gel electrophoresis $(10 \%$ polyacrylamide gel containing $0.1 \%$ sodium dodecyl sulfate; (40)). LPS samples were sonicated gently prior to electrophoresis, and then the gel was stained with silver nitrate stain.

\section{Limulus Amoebocyte Lysate (LAL) Assays}

The endotoxin activity of the LPS samples was measured with the Limulus amoebocyte assay for LPS or endotoxin (41). The Limulus endotoxin assay is a test developed from the blood cells of the horseshoe crab that detects miniscule amounts of endotoxins in fluids. All assays were conducted in 96-well microplate; a computer-controlled Bio-Rad microplate reader was used. A turbidimetric assay was 
used, in which the increasing turbidity caused by the gelation of the Limulus lysate in response to LPS was followed over time. Samples were prepared in a volume of $0.2 \mathrm{ml}$. LPS preparations from the following bacteria: $P$. denticola, $F$. nucleatum, and $P$. gingivalis, were prepared at concentrations of 0.1 to $100 \mathrm{ng} / \mathrm{ml}$. Highly purified LPS from $E$. coli $\mathrm{K} 235$ was used to prepare the standards over a concentration range of 0.1 $\mathrm{ng} / \mathrm{ml}$ to $10 \mathrm{ng} / \mathrm{ml}$. E.coli LPS was used as a positive control. The assay was initiated by addition of $50 \mu \mathrm{l}$ of Limulus lystate reagent to each well containing appropriate dilutions of LPS. The samples were read at an absorbance of $450 \mathrm{~nm}$. Plots were made of the absorbance of each sample over time, and the curves were compared with those of the E. coli LPS standards. The activity of each LPS sample in causing gelation of Limulus lysate was expressed in units corresponding to the activity of $1 \mathrm{ng} / \mathrm{ml}$ of E.coli LPS.

\section{Preparation of Monocytes}

THP-1, originally isolated from a child with acute leukemia, are mature cells in the monocyte/macrophage lineage with a normal diploid karyotype, and they produce TNF- $\alpha$ and other cytokines in response to purified endotoxin. These non-adherent cells were maintained in continuous culture with RPMI 1640 (GIBCO/BRL, Grand Island, N.Y.), $10 \%$ fetal bovine serum (GIBCO/BRL), and $0.05 \mathrm{mM} 2$-mercaptoethanol (GIBCO/BRL) in an atmosphere of $5 \% \mathrm{CO}_{2}$ at $378^{\circ} \mathrm{C}$. The doubling time for these cells under these conditions is approximately $48 \mathrm{~h}$. THP-1 cells were treated with phorbol 12-myristate 13 -acetate $\left(10^{-7} \mathrm{M}\right.$; Calbiochem Co., La Jolla, Calif.) to induce maturation of the monocytes and became macrophage-like; differentiated macrophages were identified by morphological features and their ability to adhere to plastic. Before experimentation or treatment with phorbol-12-myristate-13-acetate, THP-1 cells were washed three times with culture medium without fetal bovine serum and resuspended to a concentration of $1 \times 10^{6}$ cells per ml. Cell viability was determined to be $95 \%$ by the trypan blue dye exclusion assay. Different concentrations of bacterial LPS $(1,10$, and 25 $\mu \mathrm{g} / \mathrm{ml})$ were added and incubated for 72 hours. Supernatant fluids were collected, centrifuged and assayed for the cytokines TNF- $\alpha$ and IL-1 $\beta$ by ELISA.

\section{Cytokine Assay}

Monocytes (THP-1 cells) were prepared as described above. ELISA kits from R\&D Systems were employed to measure the concentration of TNF- $\alpha$ and IL- $\beta$ released from the THP-1 cells when stimulated with LPS of $P$. gingivalis, $P$. denticola, and $F$. nucleatum. E. coli LPS served as the control. The standard for both assays was reconstituted using deionized water producing a stock solution of $10,000 \mathrm{pg} / \mathrm{ml}$, the standard was allowed to sit for 15 minutes with gentle agitation prior to making dilutions. $405 \mu \mathrm{l}$ of Reagent Diluent consisting of 1\% Bovine Serum Albumin (BSA) in Phosphate Buffered Solution (PBS), $\mathrm{pH}$ 7.2-7.4 was added to $45 \mu \mathrm{l}$ of the stock solution in a tube to produce a standard with a concentration of $1000 \mathrm{pg} / \mathrm{ml}$; this $1000 \mathrm{pg} / \mathrm{ml}$ standard serves

as the high standard. An assay dilution series was produced by pipiting equal amounts of reagent diluent and the standard into the remaining tubes; this produced a dilution series 
with the following concentrations: $1000 \mathrm{pg} / \mathrm{ml}, 500 \mathrm{pg} / \mathrm{ml}, 250 \mathrm{pg} / \mathrm{ml}, 125 \mathrm{pg} / \mathrm{ml}, 62.5$ $\mathrm{pg} / \mathrm{ml}, 31.2 \mathrm{pg} / \mathrm{ml}$, and $15.6 \mathrm{pg} / \mathrm{ml}$. The Reagent Diluent served as the zero standard. Enclosed microplate strips were used for all assays, the microplates were coated with a mouse monoclonal antibody against human TNF- $\alpha$ or IL-1 $\beta$ depending upon which cytokine being measured in an experiment. The first column held the standard dilution series and the additional columns held the samples being tested. The concentrations of LPS tested for the periodontal pathogens were $1 \mu \mathrm{g} / \mathrm{ml}$ to $25 \mu \mathrm{g} / \mathrm{ml} .50 \mu \mathrm{l}$ of Assay Diluent was added to each well followed by $200 \mu \mathrm{l}$ of standard, control, or sample; this was incubated at room temperature for 2 hours. Following incubation, each well was aspirated and washed 4 times with wash buffer; the wash buffer consisted of $0.05 \%$ Tween 20 in PBS. An aliquot $(200 \mu \mathrm{l})$ of conjugate consisting of a polyclonal antibody against human TNF- $\alpha$ or IL-1 $\beta$, depending upon the cytokine being measured, conjugated to horseradish peroxidase was added to each well and incubated at room temperature for 1 hour. The aspiration step was repeated and $200 \mu$ of substrate solution was added to each well and incubated at room temperature for 20 minutes. To stop the reaction, $50 \mu \mathrm{l}$ of stop solution was added to each well and the microplates were read at $450 \mathrm{~nm}$.

\section{SLPI Assay}

Monocytes (THP-1 cells) were prepared as previously described. ELISA kits from R\&D Systems were employed to measure the concentration of SLPI released from the THP-1 cells when stimulated with LPS of $P$. gingivalis, $P$. denticola, and $F$. nucleatum. E. coli served as the control. The concentrations of LPS for the periodontal pathogens tested were $1 \mu \mathrm{g} / \mathrm{ml}$ to $25 \mu \mathrm{g} / \mathrm{ml}$. The standard for the assay was reconstituted using calibrator diluent producing a stock solution of $4,000 \mathrm{pg} / \mathrm{ml}$, the standard was allowed to sit for 15 minutes with gentle agitation prior to making dilutions. $100 \mu \mathrm{l}$ of Reagent Diluent consisting of $1 \%$ Bovine Serum Albumin (BSA) in Phosphate Buffered Solution (PBS), $\mathrm{pH}$ 7.2-7.4 was added to $100 \mu \mathrm{l}$ of the stock solution in a tube to produce a standard with a concentration of 2,000 pg/ml; this 2,000 pg/ml standard serves as the high standard. An assay dilution series was produced by pipitting equal amounts of reagent diluent and the standard into the remaining tubes; this produced a dilution series with the following concentrations: $1000 \mathrm{pg} / \mathrm{ml}, 500 \mathrm{pg} / \mathrm{ml}, 250 \mathrm{pg} / \mathrm{ml}, 125$ $\mathrm{pg} / \mathrm{ml}$, and $62.5 \mathrm{pg} / \mathrm{ml}$. The Reagent Diluent served as the zero standard. Enclosed microplate strips were used for all assays, the microplates were coated with a mouse monoclonal antibody against human SLPI. The first column held the standard dilution series and the additional columns held the samples being tested. $100 \mu 1$ of Assay Diluent was added to each well followed by $100 \mu \mathrm{l}$ of standard, control, or sample; this was incubated at room temperature for 2 hours. Following incubation, each well was aspirated and washed 4 times with wash buffer; the wash buffer consisted of $0.05 \%$ Tween 20 in PBS. An aliquot $(200 \mu \mathrm{l})$ of conjugate consisting of a polyclonal antibody against human SLPI conjugated to horseradish peroxidase was added to each well and incubated at room temperature for 1 hour. The aspiration step was repeated and $200 \mu \mathrm{l}$ of substrate solution was added to each well and incubated at room temperature for 20 
minutes. $50 \mu \mathrm{l}$ of stop solution was added to each well and the microplates were read at $450 \mathrm{~nm}$.

\section{Cytokine Assay Combined with Exogenous SLPI}

Monocytes (THP-1 cells) were prepared as described above. ELISA kits from R\&D Systems were employed to measure the concentration of TNF- $\alpha$ and IL- $\beta$ released from the THP-1 cells when stimulated with LPS of $P$. gingivalis, $P$. denticola, and F. nucleatum. E. coli LPS served as the control. The standard for both assays was reconstituted using deionized water producing a stock solution of $10,000 \mathrm{pg} / \mathrm{ml}$, the standard was allowed to sit for 15 minutes with gentle agitation prior to making dilutions. $405 \mu l$ of Reagent Diluent consisting of 1\% Bovine Serum Albumin (BSA) in Phosphate Buffered Solution (PBS), $\mathrm{pH}$ 7.2-7.4 was added to $45 \mu \mathrm{l}$ of the stock solution in a tube to produce a standard with a concentration of $1000 \mathrm{pg} / \mathrm{ml}$; this $1000 \mathrm{pg} / \mathrm{ml}$ standard serves as the high standard. An assay dilution series was produced by pipiting equal amounts of reagent diluent and the standard into the remaining tubes; this produced a dilution series with the following concentrations: $1000 \mathrm{pg} / \mathrm{ml}, 500 \mathrm{pg} / \mathrm{ml}, 250 \mathrm{pg} / \mathrm{ml}, 125 \mathrm{pg} / \mathrm{ml}, 62.5$ $\mathrm{pg} / \mathrm{ml}, 31.2 \mathrm{pg} / \mathrm{ml}$, and $15.6 \mathrm{pg} / \mathrm{ml}$. The Reagent Diluent served as the zero standard. Enclosed microplate strips were used for all assays, the microplates were coated with a mouse monoclonal antibody against human TNF- $\alpha$ or IL-1 $\beta$ depending upon which cytokine being measured in an experiment. The first column held the standard dilution series and the additional columns held the samples being tested. The concentrations of LPS tested for the periodontal pathogens were $1 \mu \mathrm{g} / \mathrm{ml}$ to $10 \mu \mathrm{g} / \mathrm{ml}$. Exogenous SLPI at a concentration of $1 \mu \mathrm{g} / \mathrm{ml}$ to $10 \mu \mathrm{g} / \mathrm{ml}$ was added at the same time to the LPS being tested. $50 \mu \mathrm{l}$ of Assay Diluent was added to each well followed by $200 \mu \mathrm{l}$ of standard, control, or sample; this was incubated at room temperature for 2 hours. Following incubation, each well was aspirated and washed 4 times with wash buffer; the wash buffer consisted of $0.05 \%$ Tween 20 in PBS. An aliquot $(200 \mu \mathrm{l})$ of conjugate consisting of a polyclonal antibody against human TNF- $\alpha$ or IL-1 $\beta$, depending upon the cytokine being measured, conjugated to horseradish peroxidase was added to each well and incubated at room temperature for 1 hour. The aspiration step was repeated and $200 \mu \mathrm{l}$ of substrate solution was added to each well and incubated at room temperature for 20 minutes. To stop the reaction, $50 \mu \mathrm{l}$ of stop solution was added to each well and the microplates were read at $450 \mathrm{~nm}$.

\section{Data Analysis}

Each experiment was performed at least two times using triplicate samples. Mean values \pm SEM from triplicate samples were calculated and the significance of differences was assessed using a two-tailed Student's $t$-test. Differences in results with a $p$-value $<$ 0.05 were considered significant. 


\section{CHAPTER 4. RESULTS}

\section{Limulus Activity}

The endotoxin activities of isolated LPS from periodontal pathogens were measured first with the Limulus assay (41). Stock solutions of LPS preparations from E. coli, Aa, F. nucleatum, $P$. gingivalis, and $P$. denticola were prepared in sterile water at $10 \mathrm{ng} / \mathrm{ml}$. These solutions were placed in an ultrasonic bath for 20 seconds before use to ensure an uniform suspension. Samples of these LPS solutions were then tested for Endotoxin activity by their ability to cause gelation of Limulus amebocyte lysate over a period of 60 minutes. This is a standard measure of LPS or Endotoxin activity. The Limulus assay uses a homogenate or lystate made from the macrophage-like amebocytes taken from the blue blood (hemolymph) of the horseshoe crab (Limulus polyphemus). This lysate gels and becomes turbid in the presence of LPS and the turbidity was measured at $450 \mathrm{~nm}$. This method has a high degree of sensitivity and can detect 0.001 to $100 \mathrm{ng} / \mathrm{ml}$ LPS. As a standard we have used E. coli LPS. The activity of each LPS sample in causing gelation of Limulus lysate was expressed in units corresponding to the activity of $1 \mathrm{ng} / \mathrm{ml}$ of $E$. coli LPS. The results (Figure 4.1) show that all four LPS preparations demonstrated measurable Endotoxin activity. The Endotoxin activity of $A a$, $F$. nucleatum, and $P$. gingivalis, were almost identical, while the activity of $P$. denticola was slightly lower. The LPS activity of periodontal pathogens both had about one-third activity of the highly purified $E$. coli LPS standard.

\section{Influence of Periodontal Pathogens on Monocytes to Secrete SLPI and Cytokines}

The goal of these experiments was to determine whether SLPI is induced by monocytes in response to stimulation by the LPS of periodontal pathogens and to determine if there are any differences in the rate of secretion of SLPI by macrophages. The amount of SLPI secreted by the three periodontal pathogens selected was also compared. Isolated LPS from $P$.gingivalis, $P$. denticola, and $F$. nucleatum was added to the cultured monocytes and the supernatants were assayed for the secreted inflammatory cytokines, TNF- $\alpha$, IL-1 $\beta$, and SLPI by ELISA. E. coli LPS served as the control.

\section{TNF- $\alpha$ Secretion by THP-1 Cells in Response to LPS of Periodontal Pathogens}

TNF- $\alpha$ is a cytokine involved in systemic inflammation and is a member of a group of cytokines that stimulate the acute phase reaction. The primary role of TNF- $\alpha$ is in the regulation of immune cells. TNF- $\alpha$ was found to induce apoptotic cell death and inflammation, and to inhibit tumorigenesis and viral replication.

The goals of these experiments were to determine whether the isolated LPS from the periodontal pathogens would stimulate the THP-1 cells to secrete the inflammatory cytokine TNF- $\alpha$ and to quantify the amount of TNF- $\alpha$ secreted by the THP-1 cells. The 


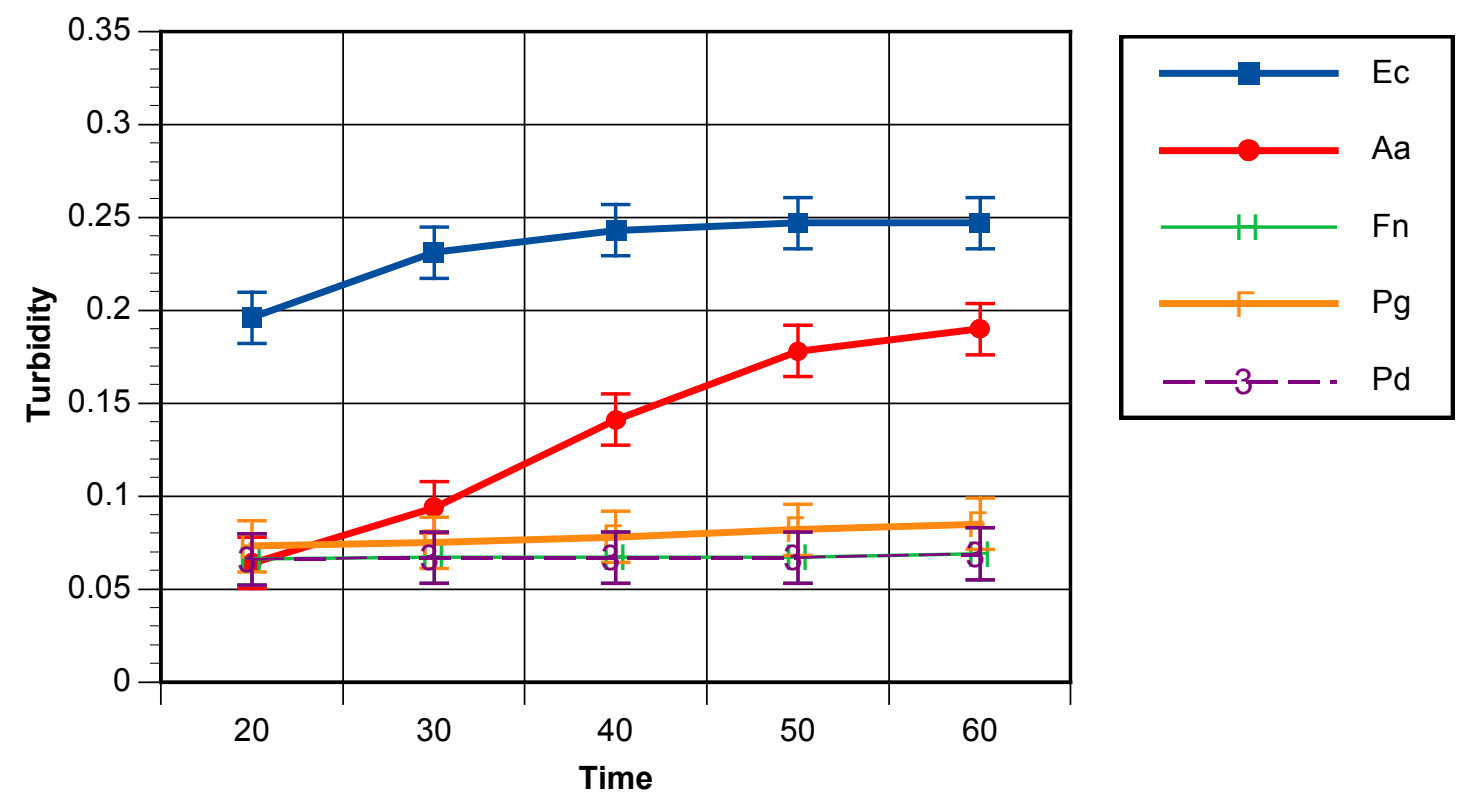

Figure 4.1 Endotoxin Activity of LPS Preparations from E. coli and Oral Pathogens at $10 \mathrm{ng} / \mathrm{ml}$. 
ELISA assay from R\&D Systems was employed to measure the concentration of TNF- $\alpha$ released from the THP-1 cells when stimulated with the LPS of $P$. gingivalis, $P$. denticola, and $F$. nucleatum. Cultured monocytes were incubated with $1 \mu \mathrm{g} / \mathrm{ml}, 10$ $\mu \mathrm{g} / \mathrm{ml}$, and $25 \mu \mathrm{g} / \mathrm{ml}$ of LPS isolated for each periodontal pathogen.

Figure 4.2 shows the secretion of TNF- $\alpha$ by the monocytes to be dose-dependent upon the concentration of the LPS. The higher the concentration of LPS caused more TNF- $\alpha$ to be secreted by the monocytes. The monocytes treated with THP cells alone secreted $13 \mathrm{pg} / \mathrm{ml}$ of TNF- $\alpha$, when the monocytes were treated with the LPS of $P$. gingivalis at a concentration of $1 \mu \mathrm{g} / \mathrm{ml}$ the amount of TNF- $\alpha$ secreted was 137.6 $\mathrm{pg} / \mathrm{ml}$ when the concentration increased to $25 \mu \mathrm{g} / \mathrm{ml}$ the amount of TNF- $\alpha$ secreted increased to $1093 \mathrm{pg} / \mathrm{ml}$ The data also showed the more pathogenic bacterial LPS from $P$. gingivalis and $P$. denticola caused a significantly $(p<0.05)$ higher amount of TNF- $\alpha$ to be secreted by the monocytes than $F$. nucleatum. The cells treated with a concentration of $25 \mu \mathrm{g} / \mathrm{ml}$ of LPS from $P$. denticola secreted $1326 \mathrm{pg} / \mathrm{ml}$ of TNF- $\alpha$ while the same concentration of $F$. nucleatum lead to only $387 \mathrm{pg} / \mathrm{ml}$ of TNF- $\alpha$ secretion. However, there were no differences in the ability of $P$. gingivalis and $P$. denticola LPS to stimulate THP-1 cells.

\section{IL-1ß Secretion by THP-1 Cells in Response to LPS of Periodontal Pathogens}

IL- $1 \beta$ is a pro-inflammatory cytokine involved in immune defense against infection. IL- $1 \beta$ is produced by macrophages, monocytes and dendritic cells. IL-1 $\beta$ increases the expression of adhesion factors on endothelial cells to enable transmigration of leukocytes to the area of infection.

The aim of these experiments were to determine whether the LPS isolated from the periodontal pathogens would encourage the THP-1 cells to secrete the proinflammatory cytokine IL- $1 \beta$ and to quantify the amount of IL- $1 \beta$ secreted by the THP-1 cells. The ELISA assay from R\&D Systems was used to measure the concentration of IL-1 $\beta$ released from the THP-1 cells when stimulated with the LPS of $P$. gingivalis, $P$. denticola, and $F$. nucleatum. Cultured monocytes were incubated with $1 \mu \mathrm{g} / \mathrm{ml}, 10$ $\mu \mathrm{g} / \mathrm{ml}$, and $25 \mu \mathrm{g} / \mathrm{ml}$ of LPS for each periodontal pathogen.

Figure 4.3 shows the secretion of IL-1 $\beta$ by the monocytes to be dose-dependent upon the concentration of the LPS. Higher concentrations of LPS lead to higher amounts of IL- $1 \beta$ to be secreted by the monocytes. The monocytes treated with THP cells alone secreted $11.7 \mathrm{pg} / \mathrm{ml}$ of IL-1 $\beta$, when the monocytes were treated with the LPS of $P$. gingivalis at a concentration of $1 \mu \mathrm{g} / \mathrm{ml}$ the amount of IL- $1 \beta$ secreted was $93 \mathrm{pg} / \mathrm{ml}$ when the concentration increased to $25 \mu \mathrm{g} / \mathrm{ml}$ the amount of IL- $1 \beta$ secreted increased to $782 \mathrm{pg} / \mathrm{ml}$ The data showed the more virulent bacterial LPS from $P$. gingivalis and $P$. denticola caused a higher amount of IL- $1 \beta$ to be secreted by the monocytes than $F$. nucleatum. The cells treated with a concentration of $25 \mu \mathrm{g} / \mathrm{ml}$ of LPS from $P$. denticola secreted $1026 \mathrm{pg} / \mathrm{ml}$ of IL-1 $\beta$ while the same concentration of $F$. nucleatum lead to only $282 \mathrm{pg} / \mathrm{ml}$ of IL- $1 \beta$ secretion. 


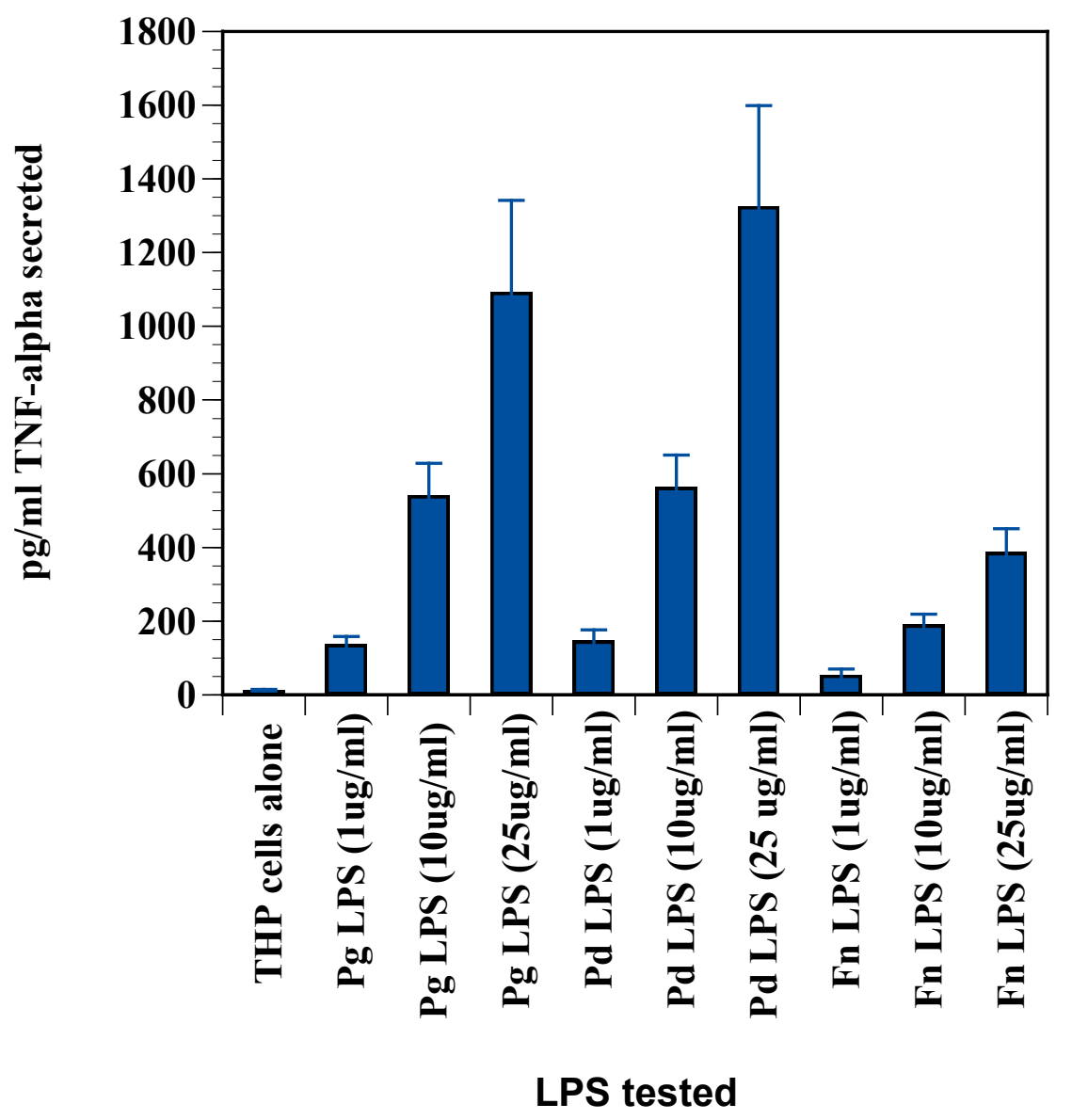

Figure 4.2 Demonstration of TNF- $\alpha$ Secretion by Cultured THP Cells in Response to LPS of Periodontal Pathogens.

The differences in stimulation by $P g$ and $P d$ LPS at all concentrations tested was found to be significantly higher than by Fn LPS $(p<0.05)$. The results are the means \pm the standard error, $\mathrm{N}=3$ run in triplicate. 


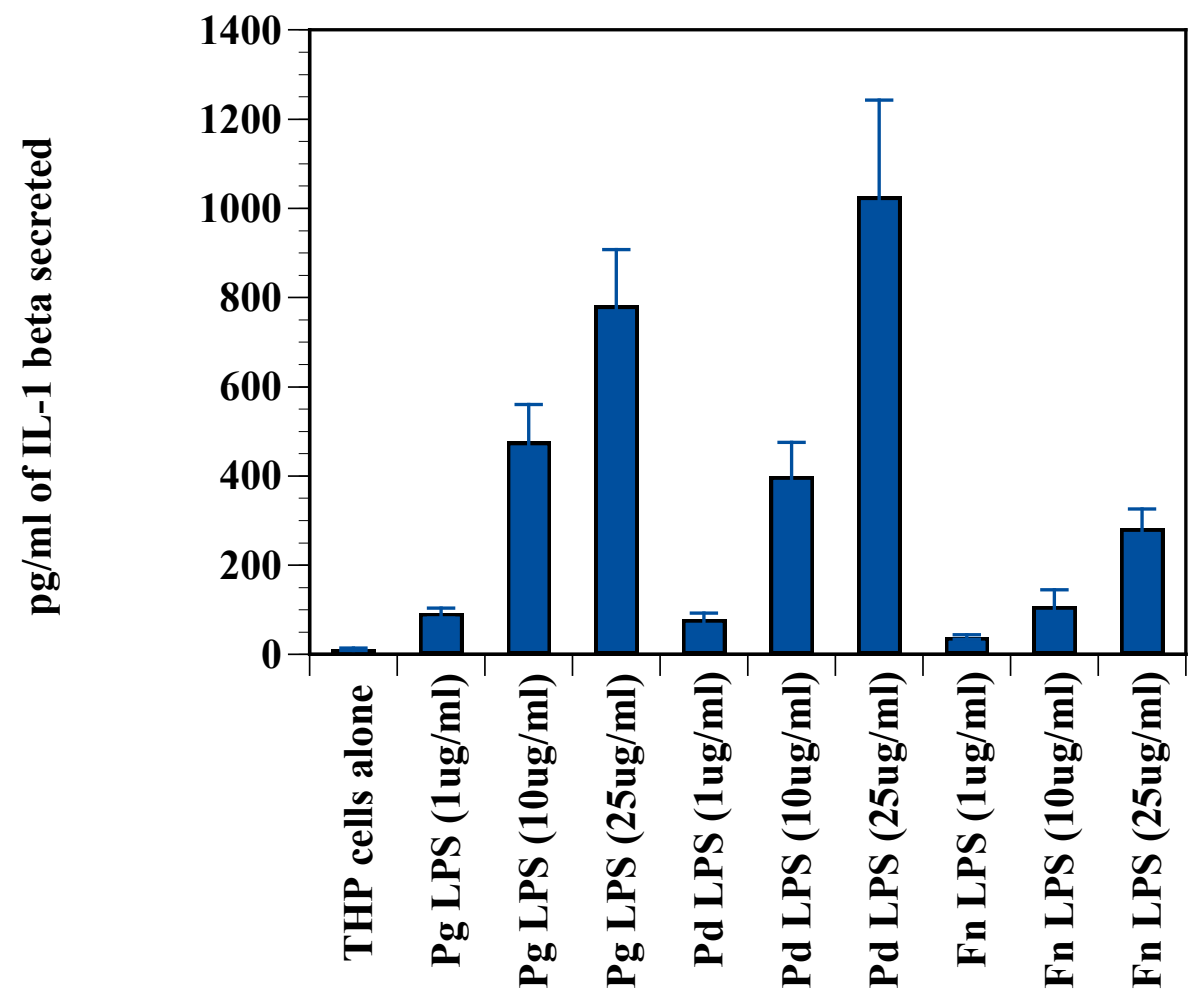

\section{LPS tested}

Figure 4.3 Demonstration of IL-1ß Secretion by Cultured THP Cells in Response to LPS of Periodontal Pathogens.

$P g$ and $P d$ LPS at a concentration of $10 \mu \mathrm{g} / \mathrm{ml}$ stimulated secretion of IL- $1 \beta$ at significantly higher $(p<0.005)$ quantities than $25 \mu \mathrm{g} / \mathrm{ml}$ of $F n$ LPS. The results are the means \pm the standard error, $\mathrm{N}=3$ run in triplicate. 


\section{SLPI Secretion by THP-1 Cells in Response to LPS of Periodontal Pathogens}

SLPI was shown to be involved in the protection of epithelial tissues from serine proteases. It is found in various secretions including seminal plasma, cervical mucus, and bronchial secretions, and has affinity for trypsin, leukocyte elastase, and cathepsin G. Its inhibitory effect contributes to the immune response by protecting epithelial surfaces from attack by endogenous proteolytic enzymes.

The aim of these experiments was to determine whether the LPS isolated from the periodontal pathogens would stimulate the THP-1 cells to secrete the protease inhibitor, SLPI. The ELISA assay from R\&D Systems was used to measure the concentration of SLPI released from the THP-1 cells when stimulated with the LPS of $P$. gingivalis, $P$. denticola, and F. nucleatum. LPS concentrations of $1 \mu \mathrm{g} / \mathrm{ml}, 10 \mu \mathrm{g} / \mathrm{ml}$, and $25 \mu \mathrm{g} / \mathrm{ml}$ for each periodontal pathogen were tested, E. coli LPS served as a control.

Figure 4.4 demonstrates the secretion of SLPI by the monocytes to be dose-dependent upon the concentration of the LPS. Higher concentrations of LPS lead to higher amounts of SLPI to be secreted by the monocytes. The monocytes treated with THP cells alone secreted $12 \mathrm{pg} / \mathrm{ml}$ of SLPI, when the monocytes were treated with the LPS of $P$. gingivalis at a concentration of $1 \mu \mathrm{g} / \mathrm{ml}$ the amount of SLPI secreted was 128 $\mathrm{pg} / \mathrm{ml}$ when the concentration increased to $25 \mu \mathrm{g} / \mathrm{ml}$ the amount of SLPI secreted increased to $876 \mathrm{pg} / \mathrm{ml}$. The data showed the more virulent bacterial LPS from $P$. gingivalis and $P$. denticola stimulated THP cells to secrete greater amounts of SLPI than $F$. nucleatum or E. coli LPS. The cells treated with a concentration of $25 \mu \mathrm{g} / \mathrm{ml}$ of LPS from $P$. denticola secreted $943 \mathrm{pg} / \mathrm{ml}$ of SLPI while the same concentration of F. nucleatum and E. coli lead to only $496 \mathrm{pg} / \mathrm{ml}$ and $118 \mathrm{pg} / \mathrm{ml}$ of SLPI secretion, respectively.

\section{Effect of Exogenous SLPI on THP-1 Cells Stimulated with LPS of $P g$ on the Secretion of IL-1 $\beta$ and TNF- $\alpha$}

Figure 4.5 demonstrates the secretion of IL- $1 \beta$ by the monocytes when treated with $P$. gingivalis to be dose-dependent as previously described with concentrations of 1 $\mu \mathrm{g} / \mathrm{ml}$ and $10 \mu \mathrm{g} / \mathrm{ml}$. However, when exogenous SLPI (1-10 $\mu \mathrm{g} / \mathrm{ml})$ was added to the cells, the amount of IL- $1 \beta$ secreted by the monocytes decreased significantly $(p<0.05)$. Monocytes treated with $P$. gingivalis $(10 \mu \mathrm{g} / \mathrm{ml})$ LPS + SLPI $(1 \mu \mathrm{g} / \mathrm{ml})$ secreted 414 $\mathrm{pg} / \mathrm{ml}$ of IL-1 $\beta$, while monocytes treated with $P$. gingivalis $(10 \mu \mathrm{g} / \mathrm{ml})$ LPS + SLPI (10 $\mu \mathrm{g} / \mathrm{ml})$ secreted $135 \mathrm{pg} / \mathrm{ml}$ of IL- $1 \beta$.

Figure 4.6 demonstrates the secretion of TNF- $\alpha$ by the monocytes when treated with $P$. gingivalis to be dose-dependent as previously described with concentrations of 1 $\mu \mathrm{g} / \mathrm{ml}$ and $10 \mu \mathrm{g} / \mathrm{ml}$. However, when exogenous SLPI (1-10 $\mu \mathrm{g} / \mathrm{ml})$ was added to the cells, the amount of TNF- $\alpha$ secreted by the monocytes decreased significantly $(p<0.05)$. Monocytes treated with $P$. gingivalis $(10 \mu \mathrm{g} / \mathrm{ml})$ LPS + SLPI $(1 \mu \mathrm{g} / \mathrm{ml})$ secreted 398 $\mathrm{pg} / \mathrm{ml}$ of TNF- $\alpha$, while monocytes treated with $P$. gingivalis $(10 \mu \mathrm{g} / \mathrm{ml})$ LPS + SLPI (10 


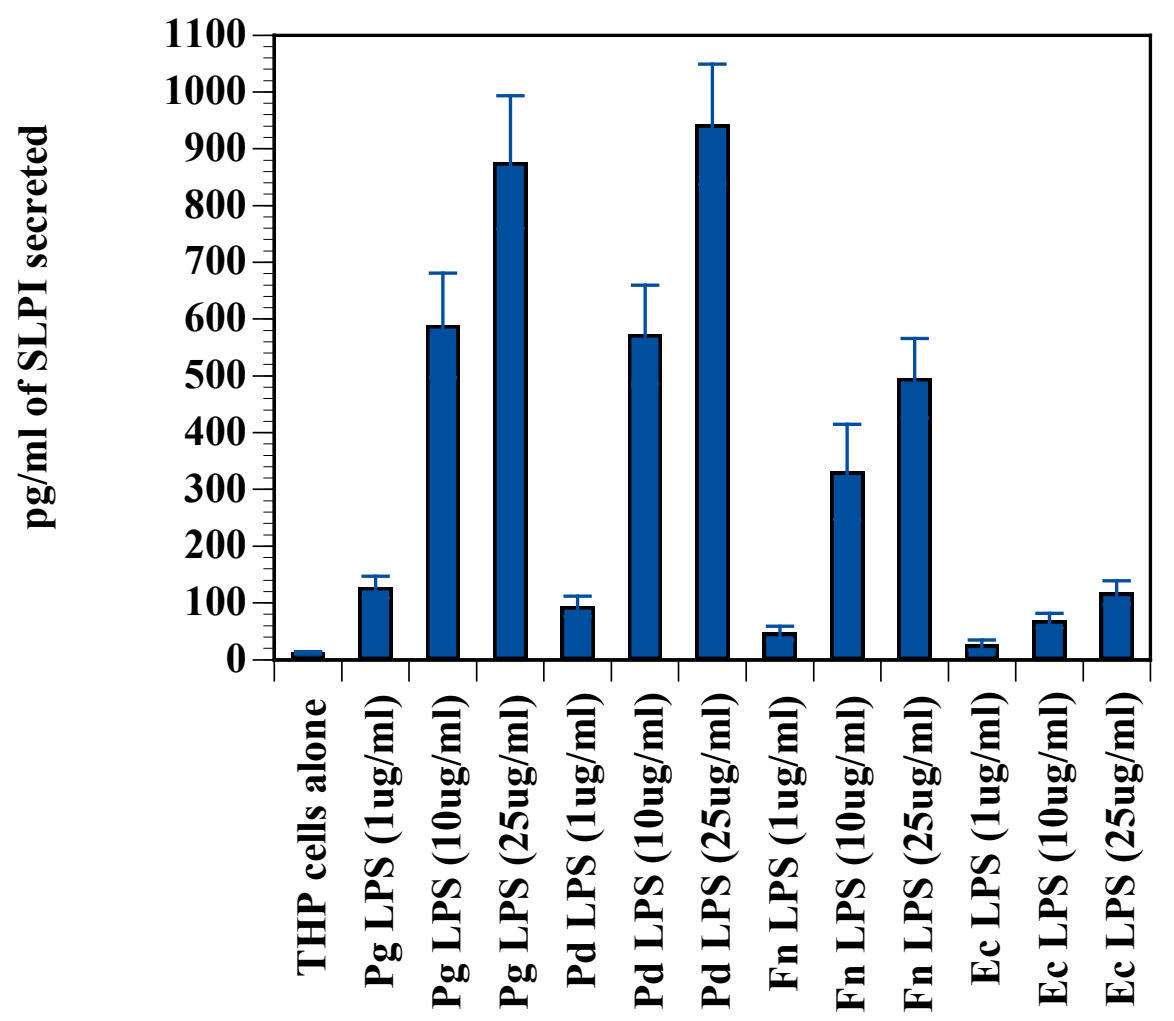

LPS tested

Figure 4.4 Demonstration of SLPI Secretion by Cultured THP Cells in Response to LPS of Periodontal Pathogens.

At $1 \mu \mathrm{g} / \mathrm{ml}$ LPS concentration of $P g$ and $P d$ the ability to stimulate secretion of SLPI was significantly different $(p<0.05)$ from $F n$ and the $E$. coli LPS control. No significant

difference was seen between $P g$ and $P d$ LPS $(25 \mu \mathrm{g} / \mathrm{ml})$. The results are the means \pm the standard error, $\mathrm{N}=3$ run in triplicate. 


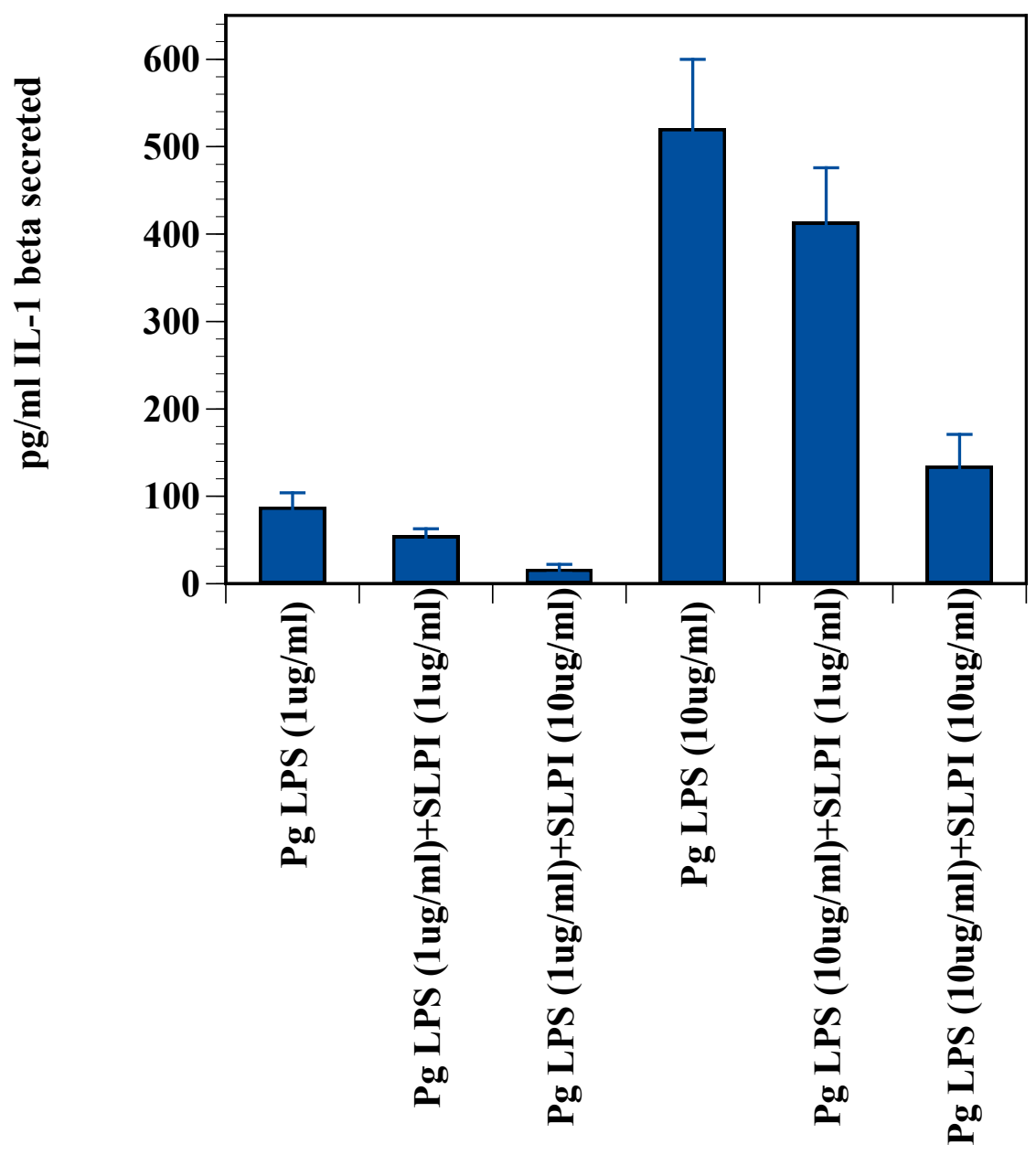

LPS tested

Figure 4.5 Effect of Exogenous SLPI on Cultured THP Cells Stimulated with LPS of $P$. gingivalis on the Secretion of IL-1ß.

The results are the means \pm the standard error, $\mathrm{N}=3$ run in triplicate. 


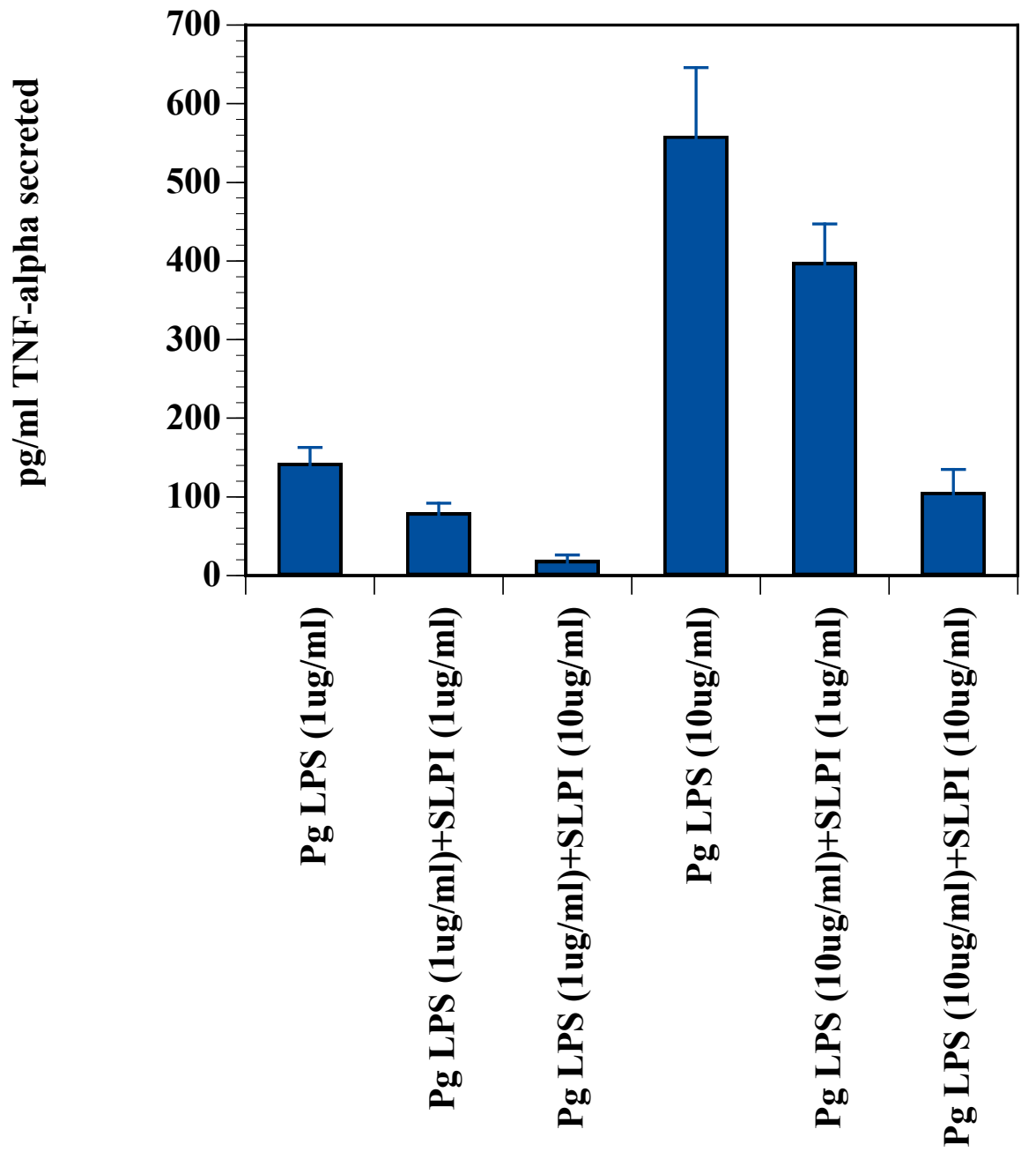

\section{LPS tested}

Figure 4.6 Effect of Exogenous SLPI on Cultured THP Cells Stimulated with LPS of $P$. gingivalis on the Secretion of TNF- $\alpha$. The results are the means \pm the standard error, $\mathrm{N}=3$ run in triplicate. 
$\mu \mathrm{g} / \mathrm{ml})$ secreted $106 \mathrm{pg} / \mathrm{ml}$ of TNF- $\alpha$.

\section{Effect of Exogenous SLPI on THP-1 Cells Stimulated with LPS of Pd on the Secretion of IL-1 $\beta$ and TNF- $\alpha$}

Figure 4.7 demonstrates the secretion of IL-1 $\beta$ by the monocytes when treated with $P$. denticola to be dose-dependent as previously described with concentrations of $1 \mu \mathrm{g} / \mathrm{ml}$ and $10 \mu \mathrm{g} / \mathrm{ml}$. However, when exogenous SLPI $(1-10 \mu \mathrm{g} / \mathrm{ml})$ was added to the cells, the amount of IL-1 $\beta$ secreted by the monocytes decreased significantly $(p<0.05)$. Monocytes treated with $P$. denticola $(10 \mu \mathrm{g} / \mathrm{ml})$ LPS + SLPI $(1 \mu \mathrm{g} / \mathrm{ml})$ secreted 323 $\mathrm{pg} / \mathrm{ml}$ of IL-1 $\beta$, while monocytes treated with $P$. denticola $(10 \mu \mathrm{g} / \mathrm{ml})$ LPS + SLPI $(10$ $\mu \mathrm{g} / \mathrm{ml})$ secreted $102 \mathrm{pg} / \mathrm{ml}$ of IL-1 $\beta$.

Figure 4.8 demonstrates the secretion of TNF- $\alpha$ by the monocytes when treated with $P$. denticola to be dose-dependent as previously described with concentrations of $1 \mu \mathrm{g} / \mathrm{ml}$ and $10 \mu \mathrm{g} / \mathrm{ml}$. However, when exogenous SLPI $(1-10 \mu \mathrm{g} / \mathrm{ml})$ was added to the cells, the amount of TNF- $\alpha$ secreted by the monocytes decreased significantly $(p<0.05)$. Monocytes treated with $P$. denticola $(10 \mu \mathrm{g} / \mathrm{ml})$ LPS + SLPI $(1 \mu \mathrm{g} / \mathrm{ml})$ secreted 406 $\mathrm{pg} / \mathrm{ml}$ of TNF- $\alpha$, while monocytes treated with $P$. denticola $(10 \mu \mathrm{g} / \mathrm{ml})$ LPS + SLPI (10 $\mu \mathrm{g} / \mathrm{ml}$ ) secreted $118 \mathrm{pg} / \mathrm{ml}$ of TNF- $\alpha$.

\section{Effect of Exogenous SLPI on THP-1 Cells Stimulated with LPS of Fn on the Secretion of IL-1 $\beta$ and TNF- $\alpha$}

Figure 4.9 demonstrates the secretion of IL-1 $\beta$ by the monocytes when treated with $F$. nucleatum to be dose-dependent as previously described with concentrations of $1 \mu \mathrm{g} / \mathrm{ml}$ and $10 \mu \mathrm{g} / \mathrm{ml}$. However, when exogenous SLPI $(1-10 \mu \mathrm{g} / \mathrm{ml})$ was added to the cells, the amount of IL-1 $\beta$ secreted by the monocytes decreased significantly $(p<0.05)$. Monocytes treated with $F$. nucleatum $(10 \mu \mathrm{g} / \mathrm{ml})$ LPS + SLPI $(1 \mu \mathrm{g} / \mathrm{ml})$ secreted 105 $\mathrm{pg} / \mathrm{ml}$ of IL-1 $\beta$, while monocytes treated with $F$. nucleatum $(10 \mu \mathrm{g} / \mathrm{ml}) \mathrm{LPS}+\mathrm{SLPI}(10$ $\mu \mathrm{g} / \mathrm{ml}$ ) secreted $51 \mathrm{pg} / \mathrm{ml}$ of IL-1 $\beta$.

Figure 4.10 demonstrates the secretion of TNF- $\alpha$ by the monocytes when treated with $F$. nucleatum to be dose-dependent as previously described with concentrations of $1 \mu \mathrm{g} / \mathrm{ml}$ and $10 \mu \mathrm{g} / \mathrm{ml}$. However, when exogenous SLPI $(1-10 \mu \mathrm{g} / \mathrm{ml})$ was added to the cells, the amount of TNF- $\alpha$ secreted by the monocytes decreased significantly $(\mathrm{p}<0.05)$. Monocytes treated with $F$. nucleatum $(10 \mu \mathrm{g} / \mathrm{ml})$ LPS + SLPI $(1 \mu \mathrm{g} / \mathrm{ml})$ secreted 150 $\mathrm{pg} / \mathrm{ml}$ of TNF- $\alpha$, while monocytes treated with $F$. nucleatum $(10 \mu \mathrm{g} / \mathrm{ml}) \mathrm{LPS}+$ SLPI (10 $\mu \mathrm{g} / \mathrm{ml})$ secreted $43 \mathrm{pg} / \mathrm{ml}$ of TNF- $\alpha$. 


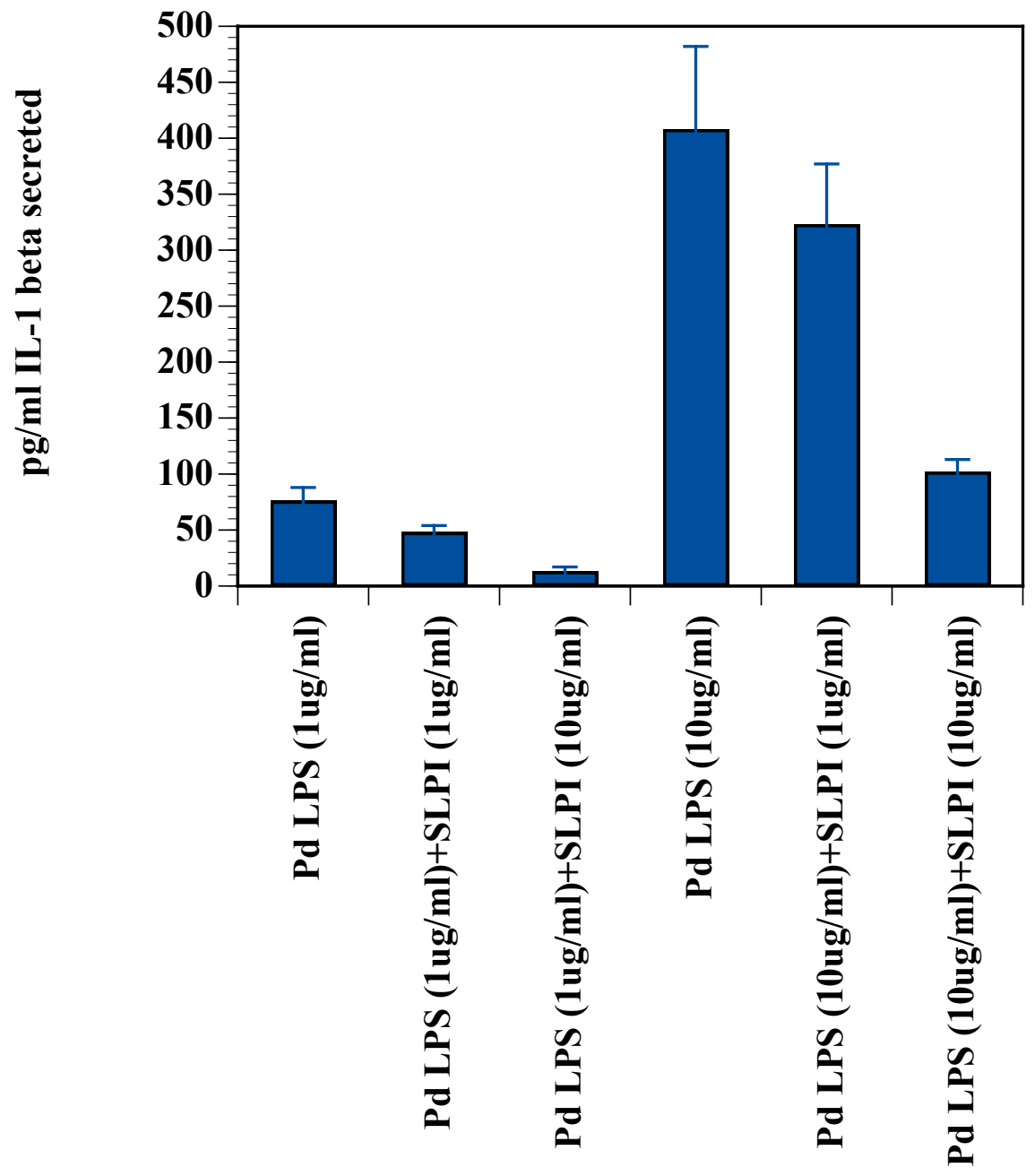

LPS tested

Figure 4.7 Effect of Exogenous SLPI on Cultured THP Cells Stimulated with LPS of $P$. denticola on the Secretion of IL-1ß.

The results are the means \pm the standard error, $\mathrm{N}=3$ run in triplicate. 


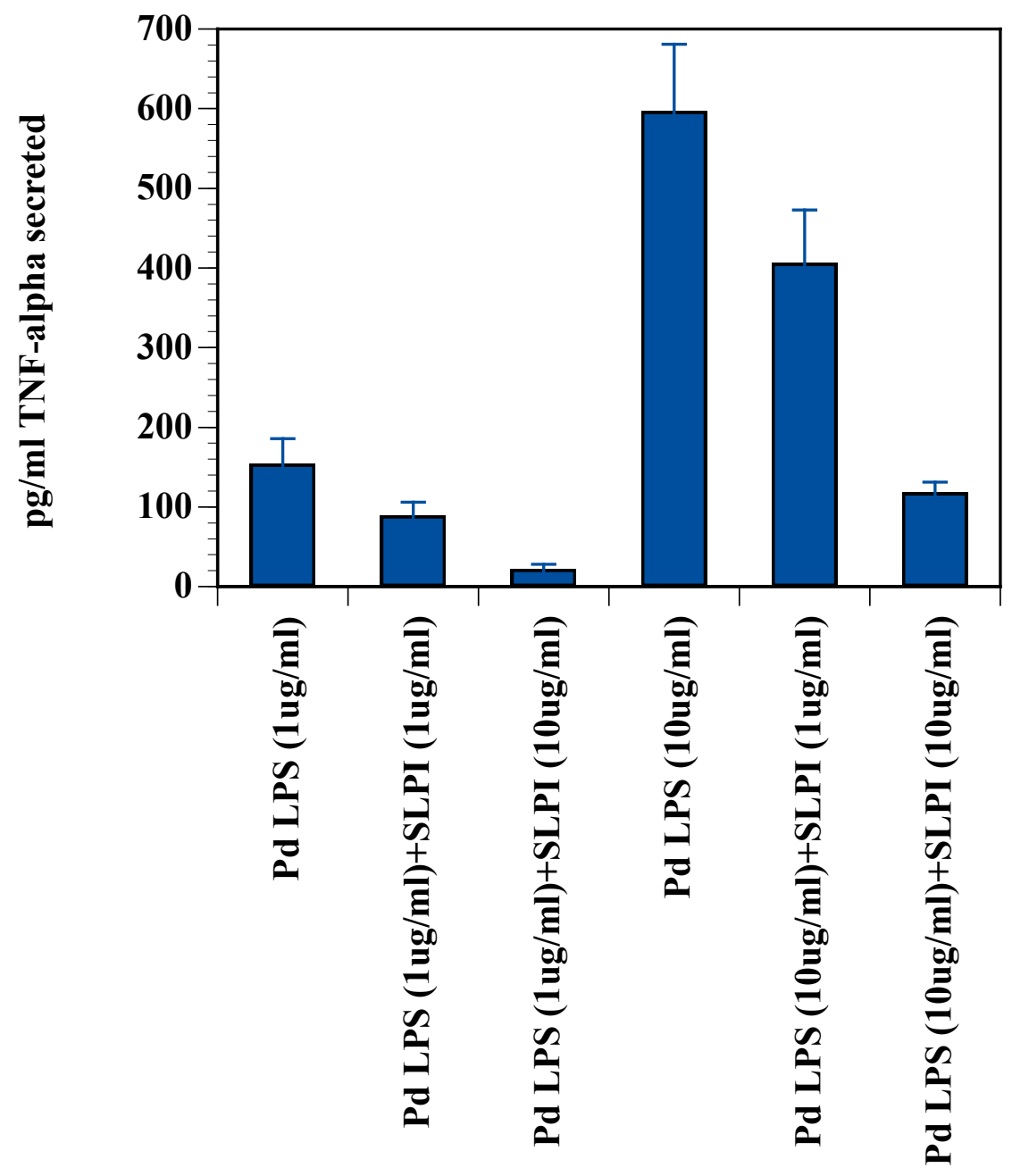

LPS tested

Figure 4.8 Effect of Exogenous SLPI on Cultured THP Cells Stimulated with LPS of $P$. denticola on the Secretion of TNF- $\alpha$.

The results are the means \pm the standard error, $\mathrm{N}=3$ run in triplicate. 


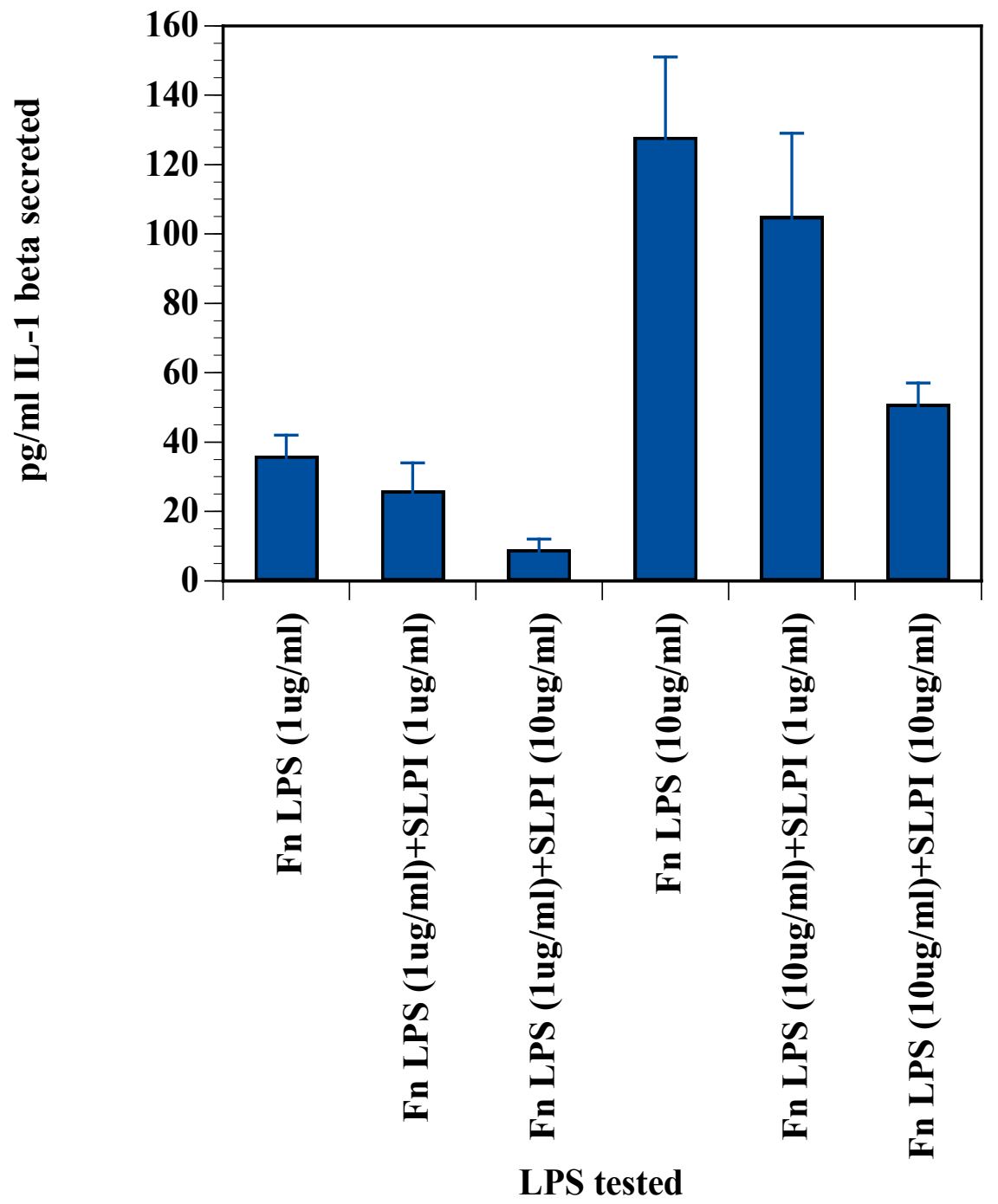

Figure 4.9 Effect of Exogenous SLPI on Cultured THP Cells Stimulated with LPS of

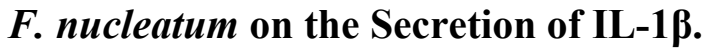

The results are the means \pm the standard error, $\mathrm{N}=3$ run in triplicate. 


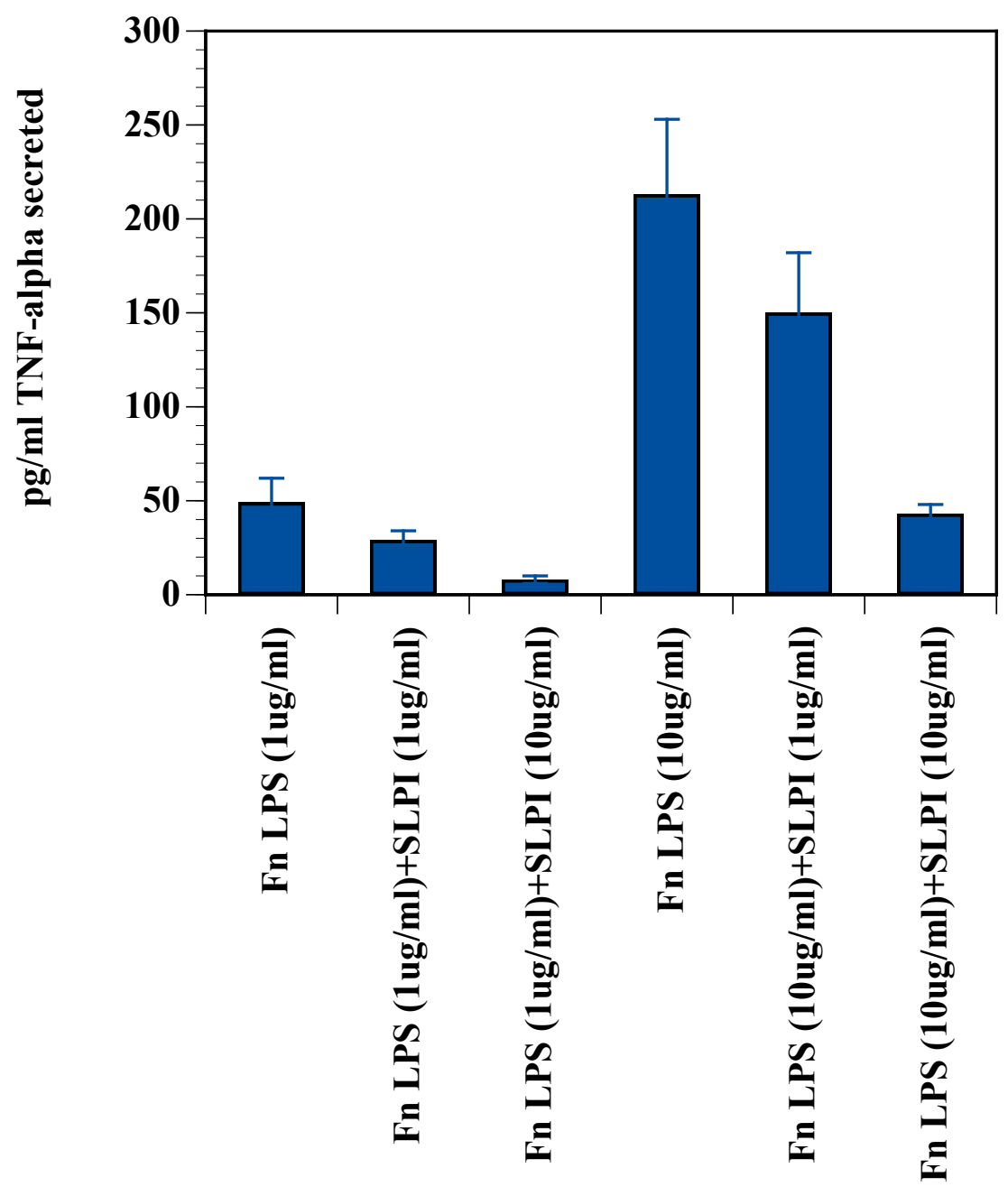

LPS tested

Figure 4.10 Effect of Exogenous SLPI on Cultured THP Cells Stimulated with LPS of $F$. nucleatum on the Secretion of TNF- $\alpha$.

The results are the means \pm the standard error, $\mathrm{N}=3$ run in triplicate. 


\section{Effect of Exogenous SLPI on THP-1 Cells Stimulated with LPS of Ec on the Secretion of IL-1 $\beta$ and TNF- $\alpha$}

Figure 4.11 demonstrates the secretion of IL-1 $\beta$ by the monocytes when treated with $E$. coli to be dose-dependent as previously described with concentrations of $1 \mu \mathrm{g} / \mathrm{ml}$ and $10 \mu \mathrm{g} / \mathrm{ml}$. However, when exogenous SLPI with a concentration of $1 \mu \mathrm{g} / \mathrm{ml}$ or $10 \mu \mathrm{g} / \mathrm{ml}$ was added to the cells, the amount of IL- $1 \beta$ secreted by the monocytes decreased significantly $(p<0.05)$. Monocytes treated with E. coli $(10 \mu \mathrm{g} / \mathrm{ml})$ LPS + SLPI $(1 \mu \mathrm{g} / \mathrm{ml})$ secreted $84 \mathrm{pg} / \mathrm{ml}$ of IL-1 $\beta$, while monocytes treated with E. coli $(10 \mu \mathrm{g} / \mathrm{ml})$ LPS + SLPI $(10 \mu \mathrm{g} / \mathrm{ml})$ secreted $29 \mathrm{pg} / \mathrm{ml}$ of IL-1 $\beta$.

Figure 4.12 demonstrates the secretion of TNF- $\alpha$ by the monocytes when treated with $E$. coli to be dose-dependent as previously described with concentrations of $1 \mu \mathrm{g} / \mathrm{ml}$ and $10 \mu \mathrm{g} / \mathrm{ml}$. However, when exogenous SLPI with a concentration of $1 \mu \mathrm{g} / \mathrm{ml}$ or 10 $\mu \mathrm{g} / \mathrm{ml}$ was added to the cells, the amount of TNF- $\alpha$ secreted by the monocytes decreased significantly $(p<0.05)$. Monocytes treated with $E$. coli $(10 \mu \mathrm{g} / \mathrm{ml}) \mathrm{LPS}+\mathrm{SLPI}(1 \mu \mathrm{g} / \mathrm{ml})$ secreted $137 \mathrm{pg} / \mathrm{ml}$ of TNF- $\alpha$, while monocytes treated with $E$. coli $(10 \mu \mathrm{g} / \mathrm{ml})$ LPS + SLPI $(10 \mu \mathrm{g} / \mathrm{ml})$ secreted $38 \mathrm{pg} / \mathrm{ml}$ of TNF- $\alpha$. 


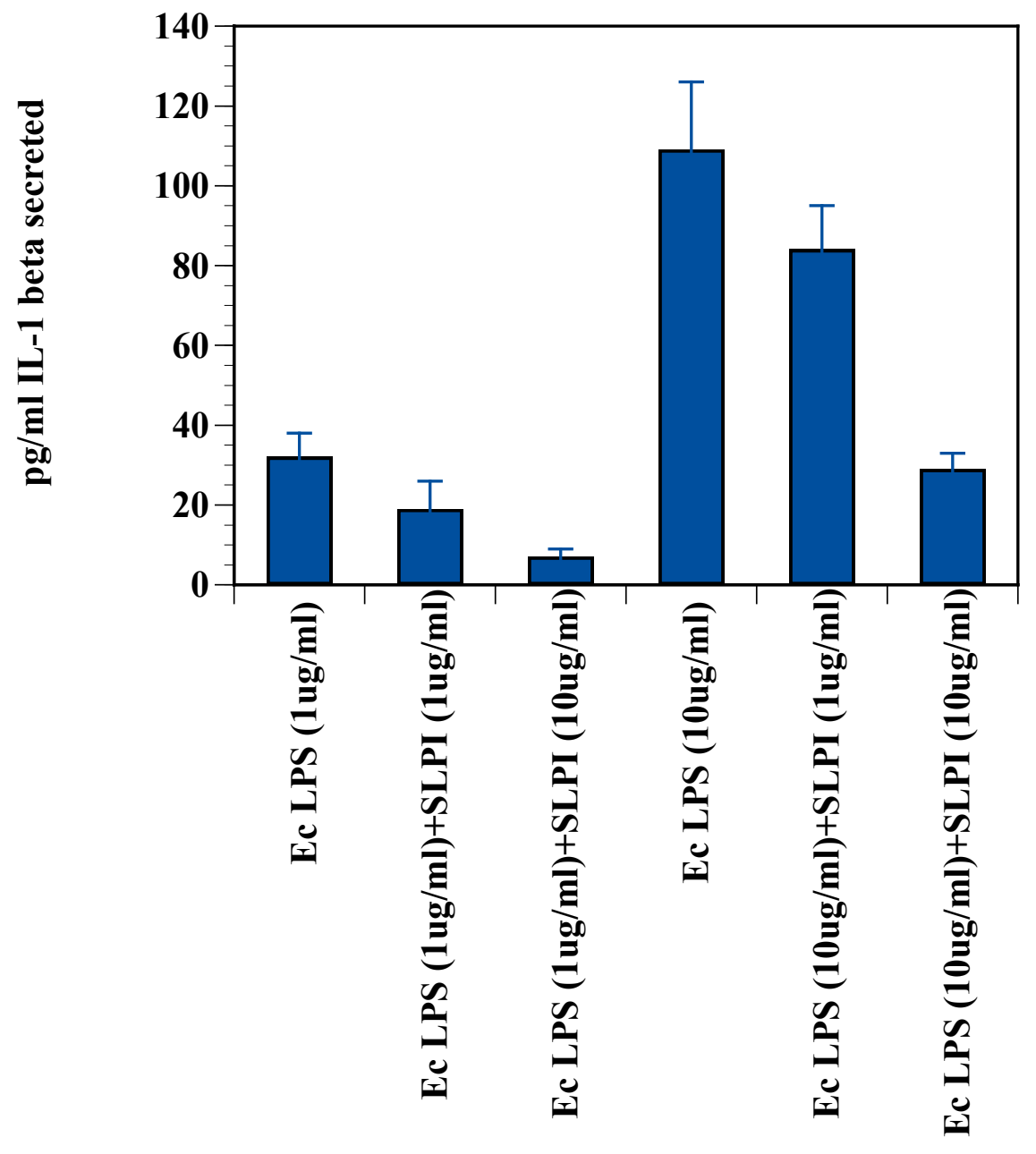

LPS tested

Figure 4.11 Effect of Exogenous SLPI on Cultured THP Cells Stimulated with LPS of $E$. coli on the Secretion of IL-1ß.

The results are the means \pm the standard error, $\mathrm{N}=3$ run in triplicate. 


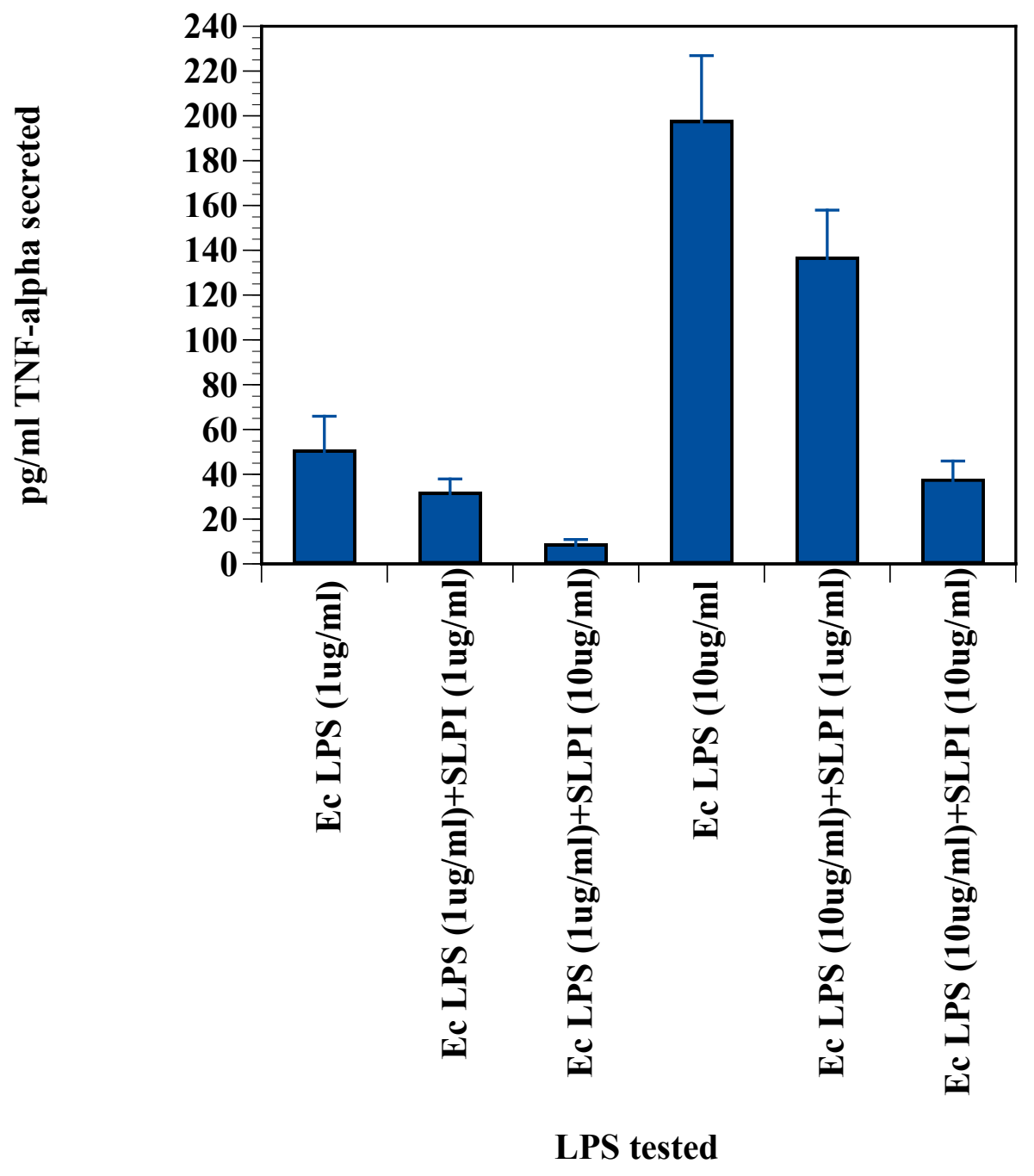

Figure 4.12 Effect of Exogenous SLPI on Cultured THP Cells Stimulated with LPS of $E$. coli on the Secretion of TNF- $\alpha$.

The results are the means \pm the standard error, $\mathrm{N}=3$ run in triplicate. 


\section{CHAPTER 5. DISCUSSION}

This study demonstrated differences in the biological functions of LPS molecule isolated from representative oral bacteria that were shown to be associated with periodontal disease. LPS from three periodontal pathogens, $P$. gingivalis, $P$. denticola, and $F$. nucleatum was isolated under identical conditions for this study in order to minimize the variations in LPS isolation. All LPS samples were found to be fairly pure, free of protein contamination when analyzed by SDS-gel electrophoresis, with molecular weights of approximately 10,000 daltons similar to the previously published studies (40).

The three LPS samples demonstrated very similar endotoxin activity when tested with the Limulus assay. The results showed that the LPS endotoxin activity of periodontal pathogens had lower endotoxin activity than the LPS of E. coli. It required at least 3-fold greater amount of LPS of periodontal pathogens to reach the level of activity attained by the LPS of E.coli. Studies have shown the variation in endotoxin activity of LPS was attributed to the lipid A structure, which seems to vary among certain bacteria (16).

The study demonstrated the interaction of LPS isolated from $P$. gingivalis, $P$. denticola, and $F$. nucleatum with cultured human monocytes. Neutrophils and monocytes are the most abundant leukocytes in circulating blood, representing greater than $50 \%$ of the cells. They are the first line of cellular defense against infection. Monocytes are attracted to a foci of infection and differentiate into macrophages, at this point the monocyte function to be either phagocytic or antigen-processing cells (14). Monocytes also produce substances called cytokines that are involved in perpetuation of inflammation and result in tissue destruction. Monocytes produce cytokines such as, IL-1 $\beta$ and TNF- $\alpha$ cytokines that exert inflammatory effects on target cells in the host $(15)$.

\section{TNF- $\alpha$ Secretion by THP-1 Cells in Response to LPS of Periodontal Pathogens}

The results of this investigation, demonstrate unique differences among the LPS of tested periodontal pathogens to stimulate TNF- $\alpha$ secretion from the monocytes. The results showed an identical concentration of LPS from $P$. gingivalis and $P$. denticola induced the monocytes to secrete approximately 4-times more TNF- $\alpha$ than that of $F$. nucleatum. The results suggest the LPS of $P$. gingivalis and $P$. denticola are more potent stimulators than the $F$. nucleatum LPS. It is possible the LPS of $P$. gingivalis and $P$. denticola may have a greater binding affinity to the active sites of the monocytes than the less pathogenic F. nucleatum. Thus, it is conceivable that a higher concentration of $F$. nucleatum was needed to attain the same degree of monocyte secretion achieved by $P$. gingivalis and $P$. denticola. Studies by Hamada et al (23) have demonstrated the LPS of gram-negative bacteria do differ structurally and functionally, and the bacteria can modify their structure to elude the host's immune defenses, this may explain the reason why $P$. gingivalis and $P$. denticola LPS behaved differently than $F$. nucleatum. 
The results showed the secretion of TNF- $\alpha$ by the monocytes to be dose-dependent, with the higher concentration of LPS of the tested periodontal pathogens stimulating the monocytes to secrete higher amounts of TNF- $\alpha$. The results suggest the TNF- $\alpha$ mediated signals can cross-talk with both the signal transduction pathways dependent on a high-affinity LPS receptor CD14 (42) and low-affinity LPS receptors, CD11c/CD18 and p73 (43). Thus, it is possible that a dose-dependent secretion of TNF- $\alpha$ by the monocytes was elicited.

\section{IL-1及 Secretion by THP-1 Cells in Response to LPS of Periodontal Pathogens}

The results of the study, demonstrate variations among the LPS of tested periodontal pathogens to stimulate IL- $1 \beta$ secretion from the monocytes. The results showed that the same concentration of LPS from $P$. gingivalis and $P$. denticola stimulated the monocytes to secrete approximately 3-times more TNF- $\alpha$ than that of $F$. nucleatum. This data indicated that the LPS of $P$. gingivalis and $P$. denticola are better stimulated than the $F$. nucleatum LPS. One possibility for this finding is the monocytes's binding affinity at their receptor sites may be higher for $P$. gingivalis and $P$. denticola than for $F$. nucleatum. It may be concluded that a greater concentration of the less pathogenic $F$. nucleatum would be required to attain a similar degree of monocyte secretion of IL-1 $\beta$ compared to $P$. gingivalis and $P$. denticola. It has been demonstrated that the LPS of gram-negative bacteria differ structurally and functionally, and this difference in structure may aid the bacteria to evade the immune response (23).

The results demonstrated a dose-dependent secretion of IL- $1 \beta$ by the monocytes, with greater concentrations of LPS from the periodontal pathogens stimulating the monocytes to secrete higher amounts of IL-1 $\beta$. This finding may suggest that the IL-1 $\beta$ mediated signals can cross-talk signal transduction pathways dependent upon highaffinity LPS receptor CD14 and low-affinity LPS receptors CD11c/CD18 (43). This may contribute to the LPS dose-dependent secretion of IL-1 $\beta$ by the monocytes.

\section{SLPI Secretion by THP-1 Cells in Response to LPS of Periodontal Pathogens}

Human SLPI is a potent inhibitor of the serine proteases trypsin, chymotrypsin, elastase, cathepsin G, chymase, and tryptase. Its only known function has been the protection of mucosal surfaces from degradation by proteases during inflammation (44), although human SLPI also displays broad-spectrum bactericidal activity (45).

Our results indicated that the LPS of the three periodontal pathogens tested induced monocytes to secrete significant amounts of SLPI. The data indicated that the same concentration of LPS from $P$. gingivalis and $P$. denticola stimulated the monocytes to secrete approximately twice the amount of SLPI than that of F. nucleatum. This data indicates that the LPS of $P$. gingivalis and $P$. denticola are more potent stimulators of monocytes to produce SLPI than $F$. nucleatum. It is possible the LPS of $P$. gingivalis and $P$. denticola may have a greater binding affinity to the active sites of the monocytes than 
the less pathogenic $F$. nucleatum. Mouse SLPI shares considerable structural homology with human SLPI but bears a variant residue at the active site (46). It has been previously established that SLPI expression in murine macrophages is induced by LPS and suppressed by gamma interferon (IFN- $\gamma$ ) and that SLPI antagonizes LPS-induced signaling and secretion (37). Thus, it is conceivable that a higher concentration of $F$. nucleatum was needed to attain the same degree of monocyte secretion achieved by $P$. gingivalis and $P$. denticola.

\section{Effect of Exogenous SLPI on Cultured THP-1 Cells Stimulated with LPS of $P g, P d$, and $F n$ on the Secretion of IL-1 $\beta$ and TNF- $\alpha$}

The results of the study demonstrated an inhibitory effect by SLPI on the LPS-induced monocyte's ability to secrete the inflammatory cytokines TNF- $\alpha$ and IL-1 $\beta$. In the experiments the addition of SLPI at a concentration of $1 \mu \mathrm{g} / \mathrm{ml}$ resulted in detectable inhibition while at a concentration of $10 \mu \mathrm{g} / \mathrm{ml}$ a dramatic suppression of TNF- $\alpha$ and IL- $1 \beta$ was observed. Inhibition of LPS responses may be a consequence of SLPI's antiprotease action. This hypothesis is consistent with the findings that serine protease inhibitor diisopropylfluorophosphate blocked LPS-induced proliferation of B cells, while trypsin partially normalized this response in B cells (47).

Alternatively, SLPI's action as an LPS inhibitor may be independent of its antiproteolytic function. Plasminogen activator inhibitor (PAI-1), another serine protease inhibitor, blocked cell migration by nonproteolytically displacing cells' integrins from their attachment to vitronectin in the extracellular matrix (48). Integrins can influence macrophage responsiveness to LPS and can serve as cofactors for macrophage activation by other agents (49). The inhibitory effect of SLPI on LPS-inducted secretion of IL-1 $\beta$ and TNF- $\alpha$ is likely to reflect interference with early steps of signaling. NF- $\kappa B$ binding sites serve as LPS-response elements in the promoters of many LPS-inducible genes, including the two products monitored in this experiment. Activation of this transcription factor was reported to be essential for LPS-induced synthesis of many inflammatory mediators, including TNF- $\alpha$, Il-1, IL-2, and IL-6 $(38,50)$. SLPI may function by engaging a membrane receptor to induce an LPS-antagonistic signal. SLPI's threedimensional structure suggests that it belongs to a protein family populated largely by neurotoxins that share equivalently placed loops held together by four similarly positioned disulfide bonds (51). Where studied, these functionally divergent proteins all act by specific binding to membrane receptors. That SLPI may bind to macrophages is consonant with the view that salivary SLPI blocks infectivity of HIV by first binding to monocytes (52). Therefore, it may be concluded that SLPI can act intracellularly to block monocyte activation by LPS and inhibit the secretion of IL-1 $\beta$ and TNF- $\alpha$. However, the exact mechanism is not clearly understood at this time.

The results of this study clearly demonstrated that LPS of periodontal pathogens differ in their ability to stimulate THP-1 cells to secrete inflammatory cytokines. LPS of pathogenic strains appears to induce secretion of greater amounts of cytokines than the less pathogenic organisms. LPS isolated from pathogenic organisms tested also induced 
the cultured THP-1 cells to secrete SLPI. In the presence of exogenous SLPI, the amounts of inflammatory cytokines secreted by THP cells in response to LPS appeared to be diminished, compared to the stimulation with LPS alone.

SLPI plays important roles in maintenance of balanced functioning of the host immune system. Although P.gingivalis is the most widely studied periodontopathic bacterium contributing to gingival inflammation, recent studies have suggested that $P$. gingivalis is also involved in inflammation in aortas, coronary vessels, and atherosclerotic plaques $(53,54)$. Therefore, the ability of pathogenic periodontal pathogens to avoid detection by the host immune cells by virtue of their ability stimulate cells to secrete SLPI. The SLPI in turn suppresses the secretion of inflammatory cytokines. These factors, taken together may aid in bacterial pathogenicity in the oral cavity leading to periodontal disease. In addition, further studies would be required to investigate the potential of SLPI to modulate the disease process. 


\section{LIST OF REFERENCES}

1. Slots, J., and Listgarten, M.: Bacteroides gingivalis, Bacteroides intermedius and Actinobacillus actinomycetemcomitans in human periodontal disease. J. Clin. Periodontol. 15:85-93, 1988.

2. Haffajee, A., and Socransky, S.: Microbial etiological agents of destructive periodontal diseases. Periodontol. 2000 5:78-111, 1994.

3. Lamont, R.J., and Jenkinson, H.F.: Life below the gum line: Pathogenic mechanism of P.gingivalis. Microbiol. Mol. Biol. Rev. 62:1244-1263, 1998.

4. Slots, J.: Bacterial specificity in adult periodontitis. J. Clin. Periodontol. 13:912917, 1986.

5. Brouckaert, P.: Tumor necrosis factor, its receptors and the connection with interleukin 1 and interleukin 6. Immunobiology 187:317-329, 1993.

6. Gemmell, E., and Seymour, G.J.: Interleukin-1, interleukin-6 and transforming growth factor-beta production by human gingival mononuclear cells following stimulation with Porphymonas gingivalis and Fusobacterium nucleatum. J. Periodontal Res. 28:122-129, 1993.

7. Aglietta, M.: In vivo effect of human granulocyte-macrophage colonystimulating factor on megakaryocytopoiesis. Blood 77:1191-1194, 1991.

8. Robertson, S.: Collagenolytic activity associated with Bacteroides species and Actinobacillus actinomycetemocomitans. J. Periodontal Res. 17:275-283, 1982.

9. Yoshima, A., Hara, Y., Kaneko, T., and Kato, I.: Secretion of IL-1 $\beta$, TNF- $\alpha$, IL-8 by human polymorphonuclear leukocytes in response to lipopolysaccharides from periodontopathogenetic bacteria. J. Periodontal Res. 32:279-286, 1997.

10. Hausmann, E., Raisz, L.D., and Miller, W.A.: Endotoxin: Stimulation of bone resorption in tissue culture. Science 168:862-864, 1970.

11. Horton, J.E., Raisz, L.G., and Simmons, H.A.: Bone resorbing activity in supernatant fluid from cultured peripheral blood leukocytes. Science 177:793$795,1972$.

12. Sataul, K.E., and Nichols, F.C.: Alteration of biological properties of bacterial lipopolysaccharides by calcium hydroxide treatment. J. Endodont. 20:127-129, 1994. 
13. Okiji, T., Morita, I., Sunada, I., and Muratas, S.: Involvement of arachidonic acid metabolites and increases in vascular permeability in experimental dental pulpal inflammation in the rat. Arch. Oral Biol. 34:523-528, 1989.

14. Van Dyke, T.E., and Serhan, C.N.: Resolution of inflammation: A new paradigm for the pathogenesis of periodontal diseases. J. Dent. Res. 82:82-90, 2003.

15. Lindemann, R.A., and Exonomou, J.S.: Actinobacillus actinomycetemcomitans and Bacteroides gingivalis activate human peripheral monocytes to produce interleukin-1 and tumor necrosis factor. J. Periodontol. 59(11):728-730, 1988.

16. Rietschel, E.T., Kirikae, T., Schade, F.U., Mamat U., Schmidt, G., Loppnow, H., Ulmer, A.J., Zahinger, U., Seydel, U., Di Padova, F., Schreier, M., and Brade, H.: Bacterial endotoxin: Molecular relationships of the structure to activity and function. FASEB J. 8:217-225, 1994.

17. Brade, H., Opal, S.M., Vogel, S.N.: Synthetic endotoxin antagonists, in Endotoxin in Health and Disease. (Morrison, D., ed.) Marcel Dekker, Inc; New York. p.950, 1999.

18. Lugtenberg, B., and Alphen, L.V.: Molecular architecture and functioning of the outer membrane of Escherichia coli and other Gram-negative bacteria. Biochem. Biophys. Acta. 737:51-115, 1983.

19. Seydel, V., Schromm, A., Blunck, R., and Brandenberg, K.: Chemical structure, molecular conformation, and bioactivity of endotoxins. Chem. Immunol. 74:5-24, 1990.

20. Raetz, C.R.: Biochemistry of endotoxins. Annu. Rev. Biochem. 59:129-170, 1990.

21. Hancock, R.E.W., and Reaves, P.: Lipopolysaccharide-deficient, bacteriophageresistant mutants in Escherichia coli K-12. J. Bacteriol. 127:98-108, 1976.

22. Hoffstad, T.: Methods for the immunological analysis of anaerobes, in Anaerobes Today. (Hardie, J., ed.) John Wiley \& Sons; Chichester, UK. p.79-85, 1988.

23. Hamada, S., Takada, H., Ogawa, T., Fujiwara, T., and Mihura, J.: Lipopolysaccharides of oral anaerobes associated with chronic inflammation: Chemical and immunomodulating properties. Intern. Rev. Immuno. 6:247-261, 1990.

24. Colwell, D.E., Michalek, S.M., Brilles, D.E., Jurillo, E., and McGhee, J.R.: Monoclonal antibodies to Salmonella lipopolysaccharide: Anti-O polysaccharide antibodies protect $\mathrm{C} 3 \mathrm{H}$ mice against challenge with virulent Salmonella typhimurium. J. Immunol. 133:950-957, 1984. 
25. Goldman, R.C. and Leive, L.: Heterogeneity of antigenic-side chain length in lipopolysaccharide from Escherichia coli 0111 and Salmonella typhimurium LT2. Eur. J. Biochem. 107:145-153, 1980.

26. Lynn, W.A., and Golenbock, D.T.: Lipopolysaccharide antagonists. Immunol. Today 13:271-276, 1992.

27. Frank, M. M., and Fries, D.A.: The role of complement in inflammation and phagocytosis. Immunol. Today 12:322-331, 1991.

28. Bone, R.C.: The pathogenesis of sepsis. Ann. Intern. Med. 115:457-469, 1991.

29. Bogdan, C., et al.: Macrophage deactivation by interleukin 10. J. Exp. Med. 174:1549-1555, 1991.

30. Dinarello, C.A.: Cytokines as mediators in the pathogenesis of septic shock. Curr. Top. Microbiol. 216:133-165, 1996.

31. Sweet, M.J., and Hume D.A.: Endotoxin signal transduction in macrophages. J. Leukoc. Biol. 60:8-26, 1996.

32. Underhill, D.M., and Ozinsky, A.: Toll-like receptors: key mediators of microbe detection. Curr. Opin. Immunol. 14:103-110, 2002.

33. Medzhitov, R.: Toll-like receptors and innate immunity. Nat. Rev. Immunol. $1: 135-145,2001$.

34. Thompson, R.C., and Ohlsson, K.: Isolation, properties, and complete amino acid sequence of human secretory leukocyte protease inhibitor, a potent inhibitor of leukocyte elastase. Proc. Natl. Acad. Sci. 83:6692, 1986.

35. Stetler, R.G.: Isolation and sequence of a human gene encoding a potent inhibitor of leukocyte proteases. Nucleic Acids Res. 14:7883-7889, 1986.

36. Fink E., Nettelbeck, R., and Fritz, H.: Inhibition of mast cell chymase by eglin-c and antileukoprotease (HUSI-I): Indications for potential biological functions of these inhibitors. Biol. Chem. Hoppe-Seyler. 367:567-572, 1986.

37. Jin, F.Y., Nathan, C., Radzioch, D., and Ding, A.: Secretory leukocyte protease inhibitor: a macrophage product induced by and antagonistic to bacterial lipopolysaccharide. Cell 88:417-425, 1997.

38. Zhu, J., Nathan, C., and Ding, A.: Suppression of macrophage responses to bacterial lipopolysaccharide by a non-secretory form of secretory leukocyte protease inhibitor. Biochim. Biophys. Acta. 1451:219-224, 1999. 
39. Westphal, O., and Jann, K.: Bacterial lipopolysaccharides; extraction with phenol-water and further applications of the procedure, in Methods in Carbohydrate Chemistry. (Whisler, R.L., ed.) Academic Press Inc., New York. p.83-91, 1965.

40. Tsai, C.M., and Frasch, C.E.: A sensitive silver stain of detecting lipopolysaccharides in polyacrylamide gels. Anal. Biochem. 119:115-119, 1982.

41. Obayashi, T., Tamura, H., Tanaka, S., Ohki, M., Takahashi, S., Arai, M., Masuda, M., and Kawai, T.: A new chromogenic endotoxin-specific assay using recombined limulus coagulation enzymes and its clinical applications. Clinica. Chimica. Acta. 149:55-65, 1985.

42. Weinstein, S., June, C., DeFranco, A.: Lipopolysaccharide-induced protein tyrosine phosphorylation in human macrophages is mediated by CD14. J. Immunol. 151:3829-3838, 1993.

43. Ingalls, R., and Golenbock, D.: CD11c/Cd18, a transmembrane signaling receptor for lipopolysaccharide. J. Exp. Med. 181:1473-1479, 1995.

44. Fink, E., Nettelbeck, R., and Fritz, H.: Inhibition of mast cells chymase by eglin c and antileukoprotease (HUSI-1). Indications for potential biological functions of these inhibitors. Biol. Chem. Hoppe-Seyler 367:567-571, 1986.

45. Hiemstra, P., Maassen, R., Stolk, J., and Dijkman, J.: Antibacterial activity of antileukoprotease. Infect. Immun. 64:4520-4524, 1996.

46. Zitnik, R., Zhang, J., Kashem, A., and Hayday, A.: The cloning and characterization of a murine leukocyte protease inhibitor cDNA. Biochem. Biophys. Res. Commun. 232:687-697, 1997.

47. Ku, G.,Quigley, J., and Sultzer, B.: Time-dependent inhibition of tuberculininduced lymphocyte DNA synthesis by a serine protease inhibitor. J. Immunol. 126:2209-2214, 1981.

48 Deng, G., Curriden, S., Wang, S., Rosenburg, S., and Loskutoff, D.: Is plasminogen activator inhibitor-1 the molecular switch that governs urokinase receptor-mediated cell adhesion and release? J. Cell Biol. 134, 1563-1571, 1996.

49. Wright, S., and Jong, M.: Adhesion-promoting receptors on human macrophages recognize E. coli by binding to lipopolysaccharide. J. Exp. Med. 164:1876-1888, 1986.

50. Lentsch, A., Yoshidome, R., Warner, P., and Edwards, J.: Secretory leukocyte protease inhibitor in mice regulates local and remote organ inflammatory injury induced by hepatic ischemia/reperfusion. Gastroenterology. 117:953, 1999. 
51. Drenth, J., Low, B., Richardson, J., and Wright, C.: The toxin-agglutinin fold. A new group of small protein structures organized around a four-disulfide core. J. Biol. Chem. 255:2652-2655, 1980.

52. McNealy, T., Dealy, M., Dripps, D., Orenstein, J., Eisenberg, S., and Wahl, S.: Secretory leukocyte protease inhibitor: a human saliva protein exhibiting antihuman immunodeficiency virus 1 activity in vitro. J. Clin. Invest. 96:456-464, 1995.

53. Deshpande, R., Khan, K., Genco, C.: Invasion of aortic and heart endothelial cells by Porphyromonas gingivalis. Infect. Immun. 66:5337-5343, 1998.

54. Bedi, G., and Williams, T.: Purification and characterization of a collagendegrading protease from Porphyromonas gingivalis. J. Biol. Chem. 269:599-606, 1994. 


\section{VITA}

Jason Todd Primm was born in Nashville, Tennessee on March 23, 1977. He received a Bachelor of Science degree in Biology from The University of Tennessee, Knoxville in 1999. He then received his D.D.S. degree from The University of Tennessee Health Science Center in 2006.

He is currently enrolled as a graduate student in the Department of Periodontology at The University of Tennessee Health Science Center. He will receive his degree of Master of Dental Science in May 2009. 